\title{
Review
}

Miguel D. Fortes, Jillian Lean Sim Ooi, Yi Mei Tan, Anchana Prathep, Japar Sidik Bujang and Siti Maryam Yaakub*

\section{Seagrass in Southeast Asia: a review of status and knowledge gaps, and a road map for conservation}

https://doi.org/10.1515/bot-2018-0008

Received 2 February, 2018; accepted 24 April, 2018; online first 29 May, 2018

\begin{abstract}
Southeast Asia has the highest diversity of seagrass species and habitat types, but basic information on seagrass habitats is still lacking. This review examines the known distribution, extent, species diversity, and research and knowledge gaps of seagrasses in Southeast Asia by biogeographic region of the Marine Ecoregions of the World (MEOW). The extent of seagrass meadows in Southeast Asia is $-36,762.6 \mathrm{~km}^{2}$ but this is likely an underestimate as some ecoregions were not well-represented and updated information was lacking. There is a paucity of information from the Western Coral Triangle Province, with no areal extent data available for the Indonesian regions of Kalimantan, Central and Southeast Sulawesi, the Maluku Islands, and West Papua. Regional research output has increased in the last two decades, with a trend towards more experimental, rather than descriptive research. However, there are knowledge gaps in socio-cultural-economic themed research, despite growing awareness of the importance of seagrass-human relationships in this region. Obstacles to advancing seagrass research, knowledge and conservation are rooted in either lack of expertise and training or the failure of effective
\end{abstract}

\footnotetext{
*Corresponding author: Siti Maryam Yaakub, Environment and Ecology Department, DHI Water and Environment (Singapore), 2 Venture Drive, \#18-18, Singapore 608526, Singapore, e-mail: smj@dhigroup.cm. http://orcid.org/0000-0002-5703-5189 Miguel D. Fortes: Marine Science Institute, CS, University of the Philippines, Diliman, QC 1101, Philippines

Jillian Lean Sim Ooi: Department of Geography, Faculty of Arts and Social Sciences, University of Malaya, Kuala Lumpur 50603, Malaysia
}

Yi Mei Tan: DHI Water and Environment (Singapore), 2 Venture Drive, \#18-18, Singapore 608526, Singapore

Anchana Prathep: Prince of Songkla University, Deparment of Biology, Faculty of Science, Hat Yai, Thailand Japar Sidik Bujang: Department of Biology, Faculty of Science, Universiti Putra Malaysia, 43400 UPM Serdang, Selangor Darul Ehsan, Malaysia. http://orcid.org/0000-0002-9797-7963 management and policies. We propose a roadmap for seagrass conservation, with suggested solutions, including 1) encouraging collaboration between research institutions and scientists in the region to build capacity and share knowledge; 2) engaging with policymakers and governments to encourage science-based policies; 3) engaging with communities to raise awareness and foster stewardship of seagrass in the region.

Keywords: conservation challenges; developing states; marine ecoregion; research gaps.

\section{Introduction}

Southeast Asia is a biologically, culturally, and ethnically diverse region, made up of 14 countries, many of which are archipelagic states (Tangsubkul 1984). The region as a whole has seen a rapid population expansion of nearly sixfold between 1900 and 2000 (Jones 2013). The current population stands at approximately 622 million people, with most of the population concentrated in coastal capital cities (Figure 1). The region is also a global biodiversity hotspot, with high numbers of endemic species in both the marine and terrestrial environments (Sodhi et al. 2010, Tittensor et al. 2010). The cost of rapid population expansion and economic development in the region has resulted in devastating losses in terms of biodiversity on land (Sodhi et al. 2004), with similar impacts on marine biodiversity, although the true extent of this is still likely not fully realised, given the paucity of information from this region (Chou 2014).

Despite being a key component of marine ecosystems, seagrass meadows are a prime example of a habitat that is largely understudied and underdocumented in the Southeast Asian region (Waycott et al. 2009), with only 62 ISI cited seagrass-related publications between the 1980s and 2010 (Ooi et al. 2011a), most of which are on two specific sites in Northwest Luzon in the Philippines, and South Sulawesi in Indonesia. Much of the literature on seagrass in this region exists as grey literature, stemming from globally funded initiatives such as the UNEP-GEF South 


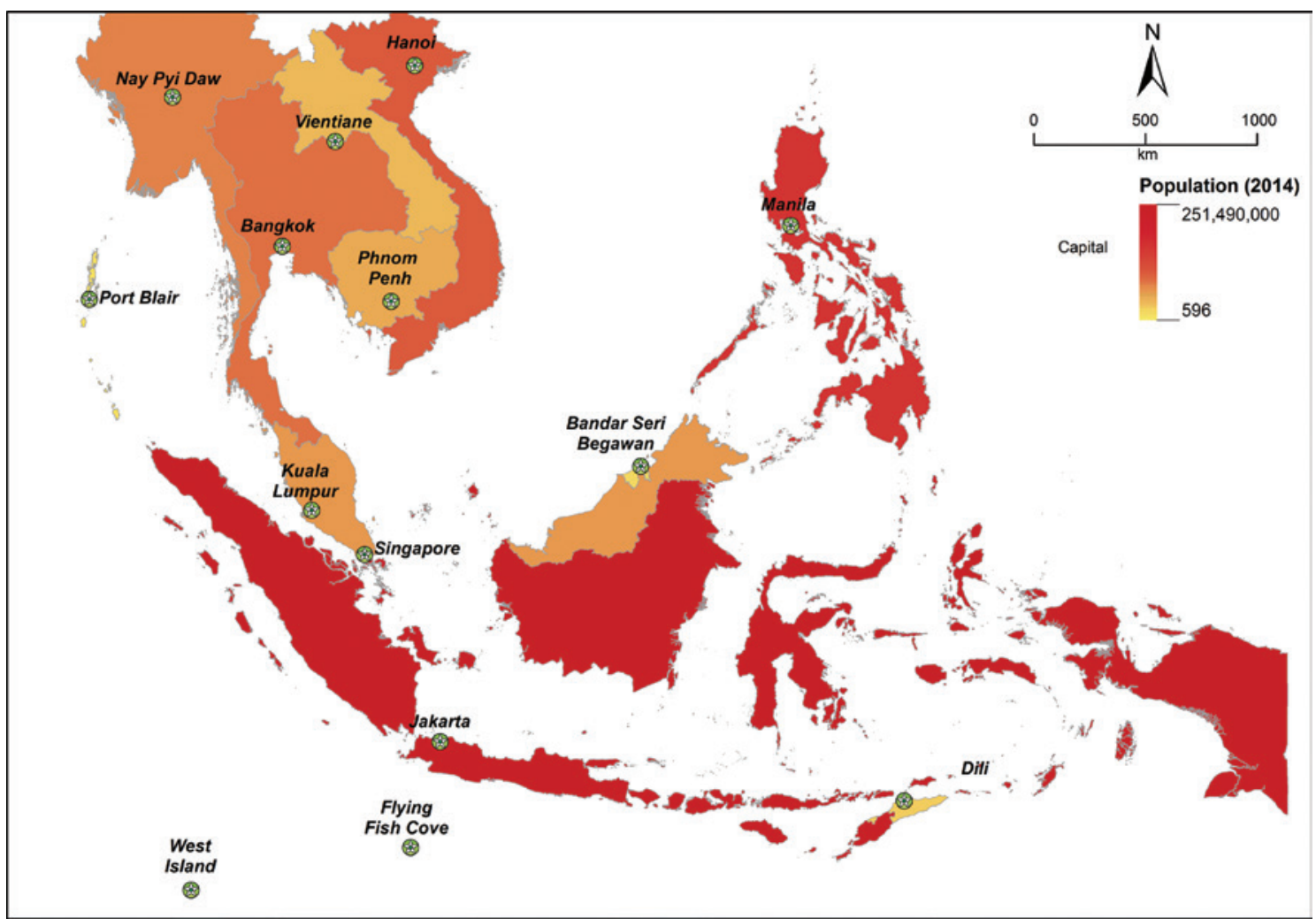

Figure 1: Total population by country in Southeast Asia. Population figures derived from www.worldatlas.com.

China Sea Project (UNEP 2008), yet these projects focus on specific areas, while excluding the wider Southeast Asian region, which is data depauperate. Seagrass meadows are widely recognised as offering a number of key ecosystem services, such as habitat formation, nutrient cycling, carbon sequestration, and food provisioning (William and Heck 2001, McGlathery et al. 2007, Fourqurean et al. 2012, Cullen-Unsworth and Unsworth 2013), with many coastal populations within Southeast Asia directly dependent on these habitats for a living (Unsworth and Cullen 2010). Seagrasses also continue to decline at a global rate of approximately 7\% (Waycott et al. 2009), and the losses may be more acute in the Southeast Asian region due to the pressure from increasing coastal populations and developments, and the lack of data on seagrass resources. Perhaps just as important are the socio-economic-cultural links between seagrass meadows and coastal populations, which is only now coming to the attention of researchers (Unsworth and Cullen 2010).

The causes of seagrass loss in Southeast Asia have been documented in two other reviews (Fortes 1995, Kirkman and Kirkman 2002), and these threats, and their associated challenges, still remain relevant today. This review paper will instead focus on the current state of knowledge of seagrass in Southeast Asia, focusing on the the extent of seagrass within the diverse biogeographic regions of its marine environments. Based on the status review, we focus on the areal gaps in knowledge within Southeast Asia, followed by a more general thematic gap analysis. We also address the conservation and management challenges based on these gaps, and propose a broad roadmap for seagrass conservation and research in Southeast Asia, in order to develop the adaptive capacity of the coastal environment and its dependent human populations.

\section{Status of seagrass in Southeast Asia \\ Seagrass distribution and extent by biogeo- graphic region}

There are six seagrass bioregions that encompass all the oceans of the world, across both tropical and temperate waters (Short et al. 2007). Southeast Asia lies within the 
Indo-West Pacific bioregion (Bioregion 5), a vast region stretching from east Africa to the eastern Pacific Ocean, notable for being the largest and most biodiverse (24 species). However, Southeast Asia itself is potentially a distinct biogeographic province within the Indo-West Pacific, as indicated by the cluster analysis by Fortes (1988) for the seagrasses of the Indo-West Pacific. The Philippines and Brunei Darussalam were also shown to be slightly differentiated from other areas because of high seagrass species numbers in the former and low species numbers in the latter (Fortes 1988), which suggests that even finer-scale regions within Southeast Asia may exist, if based on updated distribution data.

In this review, we use the Marine Ecoregions of the World (MEOW) biogeographic scheme to provide the geographical context for seagrass distribution. The MEOW biogeographic scheme classifies all coastal and shelf areas of the world according to benthic and pelagic biota (Spalding et al. 2007), producing a nested system of 12 realms, 62 provinces, and 232 ecoregions. Based on this classification, the seas of Southeast Asia consist of seven provinces and 22 ecoregions (Figure 2), extending from the Bay of Bengal and the Andaman Sea in the west, to the Arafura Sea in the east. The provinces vary in size, with the largest being the Western Coral Triangle Province, which contains seven ecoregions. The Bay of Bengal Province and Sahul Shelf Province are only partly included in what we define as Southeast Asia in this review, which explains their relatively small size in Figure 2.

Species richness at the province level is highest in the Sunda Shelf and Western Coral Triangle (15 species). Within these provinces, species richness in the individual ecoregions ranges from 3 to 14 species (Table 1), but note that we excluded Halophila gaudichaudii and Halophila tricostata from our dataset because of locational uncertainty. Low species counts were found in the CocosKeeling/Christmas Island ecoregion (3 species) and the South China Sea Oceanic Islands ecoregion (4 species). Both ecoregions are fairly isolated, comprising atolls with lagoon seagrass meadows. Low species richness here likely reflects either a limited dispersal pathway between meadows in the greater Southeast Asian region and these remote sites, or a lack of suitable ecological drivers for the majority of species in these lagoons.

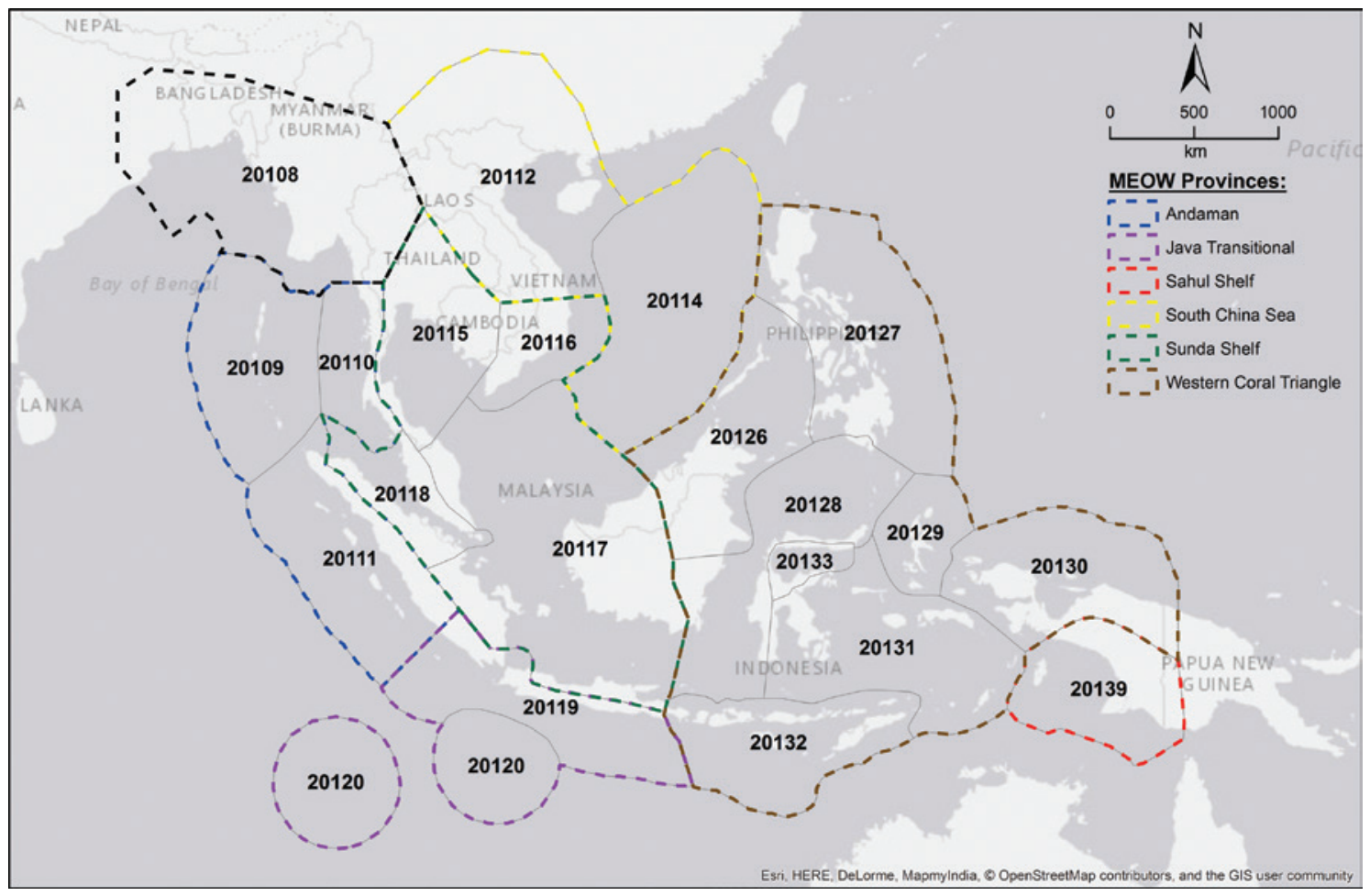

Figure 2: Marine provinces and ecoregions of Southeast Asia, based on Spalding et al. (2007).

Provinces are made out of ecoregions with the following codes: 20108 Northern Bay of Bengal; 20109 Andaman and Nicobar Islands; 20110 Andaman Sea Coral Coast; 20111 Western Sumatra; 20112 Gulf of Tonkin; 20114 South China Sea Oceanic Islands; 20115 Gulf of Thailand; 20116 Southern Viet Nam; 20117 Sunda Shelf/Java Sea; 20118 Malacca Strait; 20119 Southern Java; 20120 Cocos-Keeling/Christmas Island; 20126 Palawan/North Borneo; 20128 Sulawesi Sea/Makassar Strait; 20129 Halmahera; 20130 Papua; 20131 Banda Sea; 20132 Lesser Sunda; 20133 Northeast Sulawesi; 20139 Arafura Sea. 
Table 1: Number of seagrass species and extent of known meadows in marine bioregions of Southeast Asia.

\begin{tabular}{|c|c|c|c|}
\hline Province/ecoregion & No. of species/province & No. of species/ecoregion & Seagrass area $\left(\mathrm{km}^{2}\right)$ \\
\hline Bay of Bengal & 10 & & \\
\hline Northern Bay of Bengal (20108) & & 10 & 0.7 \\
\hline Andaman & 13 & & \\
\hline Andaman and Nicobar Islands (20109) & & 9 & 8.3 \\
\hline Andaman Sea Coral Coast (20110) & & 11 & 58.2 \\
\hline Western Sumatera (20111) & & 9 & ND \\
\hline South China Sea & 8 & & \\
\hline Gulf of Tonkin (20112) & & 5 & 36.9 \\
\hline South China Sea Oceanic Islands (20114) & & 4 & ND \\
\hline Sunda Shelf & 15 & & \\
\hline Gulf of Thailand (20115) & & 12 & 519.4 \\
\hline Southern Viet Nam (20116) & & 12 & 19.9 \\
\hline Sunda Shelf/Java Sea (20117) & & 13 & 5.2 \\
\hline Malacca Strait (20118) & & 14 & 21.7 \\
\hline Java Transitional & 12 & & \\
\hline Southern Java (20119) & & 12 & 134.4 \\
\hline Cocos-Keeling/Christmas Island (20120) & & 3 & 26.0 \\
\hline Western Coral Triangle & 15 & & \\
\hline Palawan/North Borneo (20126) & & 12 & $20,115.3$ \\
\hline Eastern Philippines (20127) & & 11 & 7158.9 \\
\hline Sulawesi Sea/Makassar Strait (20128) & & 13 & 0.9 \\
\hline Halmahera (20129) & & 5 & 402.6 \\
\hline Papua (20130) & & 8 & 5.3 \\
\hline Banda Sea (20131) & & 12 & 8246.2 \\
\hline Lesser Sunda (20132) & & 13 & 2.7 \\
\hline Northeast Sulawesi (20133) & & 5 & ND \\
\hline Sahul Shelf & 7 & & \\
\hline Arafura Sea (20139) & & 7 & ND \\
\hline
\end{tabular}

Provinces are in bold; ecoregions are in italics. ND denotes the absence of data. In assessing number of species, Halophila gaudichaudii and $H$. tricostata were excluded from this dataset because of locational uncertainty within ecoregions. Seagrass area values were available for very few sites in comparison to what we know about seagrass extent in the region, and should be regarded as underestimates.

In contrast, the Malacca Strait emerges as an ecoregion of special interest in terms of species richness. It is amongst the smallest of the ecoregions but supports 14 seagrass species (Table 1). This narrow strait, measuring $926 \mathrm{~km}$ in length, is one of the busiest shipping lanes in the world because it connects the Indian Ocean to the South China Sea (Mokhzani 2004, Ibrahim and Nazery 2007). This may partly explain its high seagrass species richness, as in the case of marine fish (Carpenter and Springer 2005). In an analysis of global shore fish biodiversity, the location of the strait in an area of overlap between Indian and Pacific ocean fauna was suggested as a likely explanation for high species richness (Carpenter and Springer 2005). In terms of gene flow, this ecoregion is recognised as the Indo-Pacific Barrier (Bowen et al. 2016), the equivalent of a marine Wallace line that separates populations of marine fauna on either side of the strait through shifts in sea level during periods of glaciation. This insight is useful in guiding the selection of sampling locations for seagrass phylogeographic studies that address questions about biodiversity distributions in Southeast Asia, and specifically in testing hypotheses about Southeast Asia as a centre of overlap, refuge, accumulation or centre-of-origin for seagrass, such as those suggested by Mukai (1993) and Nguyen et al. (2013), Nguyen et al. (2014). However, we see the need to draw attention to the fact that development in the Malacca Strait due to shipping, port construction, and land reclamation are likely factors that will determine how rapidly seagrasses, as well as other marine ecosystems, are likely to change in the near future (Mokhzani 2004, Ibrahim and Nazery 2007).

The most widespread species in Southeast Asia is Thalassia hemprichii, which had distribution records in all ecoregions, even in locations as remote as the South China Sea Oceanic Islands. Cymodocea serrulata and Cymodocea rotundata are common species as well, occurring in all ecoregions except for the South China Sea Oceanic Islands and the Cocos-Keeling/Christmas Islands. Species that 
were unique to one ecoregion were Halophila sulawesii (Kuo 2007), with only one record in Samalona Island of the Spermonde archipelago (see also: Taxonomic Highlights, below), and Zostera japonica in the Gulf of Tonkin (Luong et al. 2012). Halophila major and Halophila ovata are also limited to single ecoregions in the Northern Bay of Bengal, and the Andaman and Nicobar Islands, but this may be because these forms are taxonomically difficult to identify (addressed in Taxonomic Highlights below), although recent progress has been made in molecular approaches (Nguyen et al. 2013, 2014).

The extent of seagrass meadows in Southeast Asia is currently $36,762.6 \mathrm{~km}^{2}$ (Table 1). The largest areas are in the Palawan/North Borneo $\left(20,115 \mathrm{~km}^{2}\right)$, Eastern Philippines $\left(7159 \mathrm{~km}^{2}\right)$ and Banda Sea $\left(8246.2 \mathrm{~km}^{2}\right)$ ecoregions, all of which are part of the Western Coral Triangle Province. Not all ecoregions are as well-represented in terms of seagrass meadow estimates. The South China Sea Oceanic
Islands, Western Sumatera, Northeast Sulawesi, and the Arafura Sea ecoregions, for example, have obvious information gaps. These will be further highlighted in Section "Areal gaps in knowledge and information".

\section{Seagrass distribution and extent by country}

Recent updates now show Southeast Asia to have 21 seagrass species in nine genera and four families, which makes up $29 \%$ of the world's seagrass species (Table 2). Seagrass species diversity is highest in the Philippines (19 species), and lowest in Brunei (7 species), which is the country with the most recent additions to its species list (Lamit et al. 2017).

The nation states of Southeast Asia have a collective coastline of more than $100,000 \mathrm{~km}$ that encompass at least $675,824 \mathrm{~km}^{2}$ of territorial seas (Flanders Marine Institute

Table 2: Seagrass species distribution in Southeast Asia by country/territory. ${ }^{+}$

\begin{tabular}{|c|c|c|c|c|c|c|c|c|c|c|}
\hline Family and species & BN & ID & CM & MM & MY & PH & SG & TH & VN & $\mathrm{AN}^{+}$ \\
\hline \multicolumn{11}{|l|}{ Family Hydrocharitaceae } \\
\hline Enhalus acoroides (L. f.) Royle & $\bullet$ & $\bullet$ & $\bullet$ & $\bullet$ & $\bullet$ & $\bullet$ & $\bullet$ & $\bullet$ & $\bullet$ & $\bullet$ \\
\hline Thalassia hemprichii (Ehrenb.) Aschers. in Petermann & $\bullet$ & $\bullet$ & $\bullet$ & $\bullet$ & $\bullet$ & $\bullet$ & $\bullet$ & $\bullet$ & $\bullet$ & $\bullet$ \\
\hline Halophila beccarii Aschers. & $\bullet$ & $\bullet$ & $\bullet$ & $\bullet$ & $\bullet$ & $\bullet$ & $\bullet$ & $\bullet$ & $\bullet$ & \\
\hline Halophila decipiens Ostenfeld & & $\bullet$ & $\bullet$ & $\bullet$ & $\bullet$ & $\bullet$ & $\bullet$ & $\bullet$ & $\bullet$ & \\
\hline Halophila gaudichaudii J. Kuo & & & & & & $\bullet$ & & & & \\
\hline Halophila major (Zoll.) Miq. & & $\bullet$ & & $\bullet$ & $\bullet$ & $\bullet$ & & $\bullet$ & $\bullet$ & \\
\hline Halophila minor (Zoll.) den Hartog & & $\bullet$ & $\bullet$ & $\bullet$ & $\bullet$ & $\bullet$ & $\bullet$ & $\bullet$ & $\bullet$ & \\
\hline Halophila ovalis (R. Br.) Hook. f. & $\bullet$ & $\bullet$ & $\bullet$ & $\bullet$ & $\bullet$ & $\bullet$ & $\bullet$ & $\bullet$ & $\bullet$ & $\bullet$ \\
\hline Halophila ovata Gaudich. and in Freycinet & & & & & & $\bullet$ & & & & $\bullet$ \\
\hline Halophila spinulosa (R. Br.) Aschers. & $\bullet$ & $\bullet$ & & $\bullet$ & $\bullet$ & $\bullet$ & $\bullet$ & & & \\
\hline Halophila sulawesii J. Kuo & & $\bullet$ & & & & & & & & \\
\hline Halophila sp. 1 & & & & & & $\bullet$ & & & & \\
\hline Halophila sp. 2 (Halophila tricostata Greenway) & & & & & $\bullet$ & $\bullet$ & & & & \\
\hline \multicolumn{11}{|l|}{ Family Cymodoceaceae } \\
\hline Cymodocea rotundata Ehrenb. et Hempr. ex Aschers. & $\bullet$ & $\bullet$ & $\bullet$ & $\bullet$ & $\bullet$ & $\bullet$ & $\bullet$ & $\bullet$ & $\bullet$ & $\bullet$ \\
\hline Cymodocea serrulata (R. Br.) Aschers. et Magnus & & $\bullet$ & $\bullet$ & $\bullet$ & $\bullet$ & $\bullet$ & $\bullet$ & $\bullet$ & $\bullet$ & $\bullet$ \\
\hline Halodule pinifolia (Miki) den Hartog & $\bullet$ & $\bullet$ & $\bullet$ & $\bullet$ & $\bullet$ & $\bullet$ & $\bullet$ & $\bullet$ & $\bullet$ & $\bullet$ \\
\hline Halodule uninervis (Forssk.) Aschers. & & $\bullet$ & $\bullet$ & $\bullet$ & $\bullet$ & $\bullet$ & $\bullet$ & $\bullet$ & $\bullet$ & $\bullet$ \\
\hline Syringodium isoetifolium (Aschers.) Dandy & & $\bullet$ & $\bullet$ & $\bullet$ & $\bullet$ & $\bullet$ & $\bullet$ & - & $\bullet$ & $\bullet$ \\
\hline Thalassodendron ciliatum (Forssk.) den Hartog & & $\bullet$ & & & $\bullet$ & $\bullet$ & & & $\bullet$ & \\
\hline \multicolumn{11}{|l|}{ Family Ruppiaceae } \\
\hline Ruppia maritima L. & & $\bullet$ & $\bullet$ & & $\bullet$ & $\bullet$ & & $\bullet$ & & \\
\hline \multicolumn{11}{|l|}{ Family Zosteraceae } \\
\hline Zostera japonica Aschers. et Graebn. & & & & & & & & & $\bullet$ & \\
\hline Total no. of species & 7 & 16 & 12 & 13 & 16 & 19 & 12 & 13 & 14 & 9 \\
\hline
\end{tabular}

Country codes and references used to compile this list as follows: BN, Brunei (Fortes 1988, Lamit et al. 2017); ID, Indonesia (Kuo 2007, Wawan 2011, Tuntiprapas et al. 2015); CM, Cambodia (UNEP 2008, Vibol et al. 2010); MM, Myanmar (Novak et al. 2009, Soe-Htun et al. 2009, Nguyen et al. 2014, BOBLME 2015); MY, Malaysia (Japar Sidik and Muta Harah 2011, Nguyen et al. 2014); PH, Philippines (Fortes 1989, Waycott et al. 2002, Fortes 2013, Kim et al. 2017); SG, Singapore (Yaakub et al. 2013); TH, Thailand (Nguyen et al. 2014, Tuntiprapas et al. 2015); VN, Viet Nam (Nguyen et al. 2013, 2014); AN, Andaman and Nicobar Islands (Jagtap et al. 2003, Tangaradjou et al. 2010), the “+” denoting this is a union territory of India. 
2016). The Philippines has the largest seagrass extent, with seagrass meadows constituting at least $24 \%$ of its territorial waters - the largest proportion in the region (Table 3). In contrast, Myanmar and Malaysia have the lowest proportion of known seagrass areas relative to the size of their territorial seas $(\leq 0.02 \%)$, while Timor-Leste has yet to produce areal estimates of seagrass meadows. This provides a guide to which countries in particular require greater capacity-building in developing spatial databases for seagrass.

\section{Taxonomic notes}

The seagrass species list of Southeast Asia (Table 2) shows 21 species, but some of these are still considered taxonomically uncertain. The genus with the greatest number of unvalidated species is Halophila. This genus has high taxonomic diversity, but its constituent forms appear to have overlapping leaf morphologies that have made validation problematic. The plasticity of this species in response to different substratum, salinity, and light regimes has been demonstrated (Young and Kirkman 1975, Benjamin et al. 1999, Japar Sidik et al. 2010), and is the main reason for taxonomic uncertainty on the basis of morphological traits alone. In Table 2, we show Halophila to consist of nine recognised species and two undescribed species, Halophila sp. 1 (the Philippines) and Halophila sp. 2 (Malaysia and Philippines). Amongst those we list as recognised species, however, we acknowledge that $H$. major, $H$. gaudichaudii, $H$. minor, and $H$. ovata, which are regarded as being part of the $H$. ovalis complex (Waycott et al. 2004), which may now include $H$. sulawesii, are undergoing taxonomic scrutiny in this region, which we briefly summarise below.

In Southeast Asia, Halophila major has been studied in greater detail than other species in its genus, through a combination of morphological and molecular traits. As a result, it has become a recent entry into the species records of Indonesia (Tuntiprapas et al. 2015), Thailand (Tuntiprapas et al. 2015), Malaysia (Japar Sidik pers. obs; see Figure 3), Myanmar (Nguyen et al. 2014), Viet Nam (Nguyen et al. 2013, 2014), and the Philippines (Kim et al. 2017). Halophila minor and Halophila ovata were treated as synonyms for the seagrass flora of Singapore (Yaakub et al. 2013) despite being recognised as two distinct species by Kuo (2000). However, H. ovata was subsequently considered an illegitimate name and proposed as Halophila gaudichaudii by Kuo et al. (2006). As a result, all these

Table 3: Extent of known seagrass areas in Southeast Asia, arranged according to seagrass area size for each country. ${ }^{\mathrm{a}}$

\begin{tabular}{|c|c|c|c|c|}
\hline Country/Territory+ & $\begin{array}{r}\text { Coastline } \\
\text { extent }(\mathrm{km})\end{array}$ & $\begin{array}{l}\text { Seagrass } \\
\text { area }\left(\mathrm{km}^{2}\right)\end{array}$ & $\begin{array}{l}\text { Proportion of territorial } \\
\text { seas with seagrass (\%) }\end{array}$ & Source \\
\hline Philippines & 36,289 & $27,262.2$ & 24.24 & World Bank 2005 \\
\hline Indonesia & 80,791 & 8812.9 & 3.06 & $\begin{array}{l}\text { Neinhuis et al. 1989, de longh et al. 1995, Douven et al. 2003, } \\
\text { Arifin 2004, Kuriandewa and Supriyadi 2006, UNEP 2008, Kamal } \\
\text { et al. 2010, Unsworth 2010, van Katwijk et al. 2011, Torres- } \\
\text { Pulliza et al. 2013, Patty 2016, Kawaroe et al. 2016, Fitrian et al. } \\
\text { 2017, Mintje } 2017\end{array}$ \\
\hline Cambodia & 435 & 324.9 & 6.19 & UNEP 2008 \\
\hline Thailand & 2583 & 148.5 & 0.29 & Poovachiranon et al. 2006, UNEP 2008 \\
\hline Viet Nam & 3200 & 157.4 & 0.25 & Luong et al. 2012 \\
\hline $\begin{array}{l}\text { Cocos-Keeling/Christmas } \\
\text { Island }^{+}\end{array}$ & 26 & 26.0 & - & Hobbs et al. 2007 \\
\hline Malaysia & 4800 & 16.3 & 0.02 & $\begin{array}{l}\text { Japar Sidik and Muta Harah 2003, Jaaman et al. 2011, } \\
\text { Anscelly 2014, Ooi et al. 2014, Rajamani and Marsh 2015, } \\
\text { Hossain et al. 2015a,b, Japar Sidik and Muta Harah } 2011\end{array}$ \\
\hline Andaman and Nicobar ${ }^{+}$ & 1962 & 8.3 & - & Tangaradjou et al. 2010 \\
\hline Myanmar & 3060 & 4.3 & 0.01 & BOBLME 2015 \\
\hline Brunei & 161 & 1.5 & 0.05 & Lamit et al. 2017 \\
\hline Singapore & 193 & 0.3 & 0.04 & Yaakub et al. 2013 \\
\hline Timor-Leste & 706 & Unknown & Unknown & - \\
\hline Total & 117,763 & $36,762.6$ & & \\
\hline
\end{tabular}

Proportion of territorial seas with seagrass was calculated for each country or territory based on territorial sea area values obtained from Flanders Marine Institute (2016). ${ }^{+}$Cocos Keeling/Christmas Island and Andaman and Nicobar Islands are territories of Australia and India

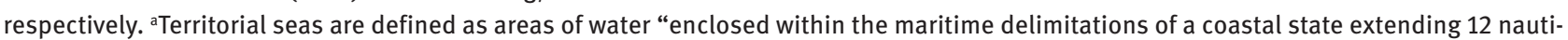
cal miles seawards from the baselines" (Flanders Marine Institute 2016). Estimates were not made for territories. Seagrass area values were available for very few sites in comparison to what we know about seagrass extent in the region, and should be regarded as underestimates. 


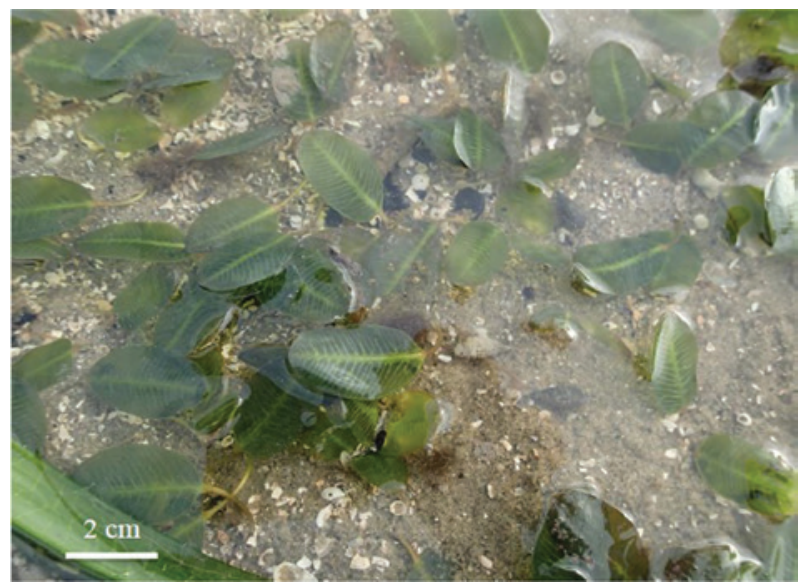

Figure 3: Halophila major from Tanjung Adang Laut, Sungai Pulai estuary, Johor (refer also to Nguyen et al. 2014 for morphological and genetic identification of the species).

Photo credit: () Muta Harah.

confounding species, i.e. H. minor, $H$. ovata and $H$. gaudichaudii are present in the species records of this region, and are reported as such in this review on the grounds of maintaining the transparency of these species lists until a taxonomic consensus is reached. We note, however, that H. major appeared in the records of Viet Nam (Southern Viet Nam ecoregion) and Myanmar (Northern Bay of Bengal ecoregion); $H$. gaudichaudii in the records of the Philippines (ecoregion undetermined); and $H$. ovata in the Andaman and Nicobar Islands, and the Philippines (ecoregion undetermined).

In Table 2, there are two unidentified Halophila species, i.e. Halophila sp. 1 from Malita, Davao del Sur, the Philippines (Fortes 2013) and Halophila sp. 2, from a mangrove area of Teluk Sepinong, Sandakan, Sabah, Malaysia (Japar Sidik and Muta Harah 2011). Halophila sp. 1 needs further verification. However, Halophila sp. 2 (Figure 4), was also reported as an uinidentified Halophila sp. nov., collected off Molleangan Island, near Banggi Island, Sabah (Rajamani and Marsh 2015), which has recently been described and identified as Halophila tricostata using molecular ITS sequence data in the Philippines (Calumpong et al. 2010, Tiongson 2012). Halophila tricostata is considered endemic to the east coast of Australia (Greenway 1979) and its presence in the species records of Southeast Asia indicates its potential for long distance dispersal from the Great Barrier Reef of Australia to the Palawan/North Borneo ecoregion.

The genus Halodule is another taxon that has been a source of uncertainty and confusion in species identification because of overlapping morphological characters (leaf width, leaf length dimensions) and species

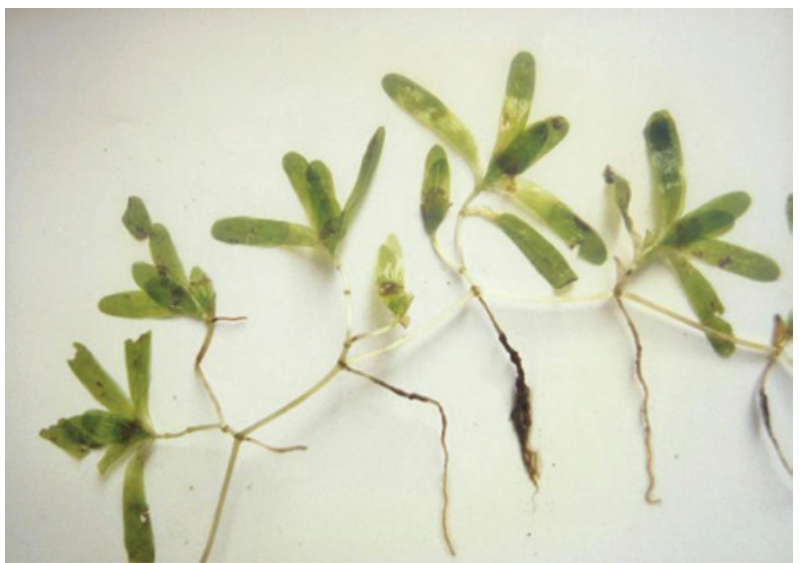

Figure 4: Halophila sp. 2 collected in 1997 at a mangrove area of Teluk Sepinong, Sandakan, Sabah, Malaysia.

Photo credit: (c) Japar Sidik.

separation through their leaf tips (Phillips 1967, den Hartog 1970, Japar Sidik et al. 1999). Halodule pinifolia is considered to be the narrow-leaved form of Halodule uninervis (Waycott et al. 2004), but these have been shown through genetic analysis on samples in the Philippines to be separate species that have morphological variations in leaf width because of site-specific differences, density and exposure (Wagey and Calumpong 2013). Thus, we have maintained them as different species in Table 2.

\section{Knowledge gaps}

\section{Areal gaps in knowledge and information}

Information on seagrass in Southeast Asia is geographically unbalanced, with hotspots and coldspots of research effort. Within hotspots, the level of information itself is variable, with some providing reports of species presence, while others provide both species presence and estimates of meadow size. Estimates of meadow size are rarely reported because of the logistical challenges in mapping seagrass meadows. It has only been in recent years that areal estimates for seagrass meadows have begun to emerge more rapidly as a result of advancements in remote sensing technology and well-funded regional projects such as the UNEP/GEF South China Sea Project (UNEP 2008), the Bay of Bengal Large Marine Ecosystem Project (BOBLME 2015), and the JSPS-Asian CORE Project. We consider meadow size data to be particularly critical for moving seagrass conservation and management forward in the region because these provide 
baselines for understanding ecosystem trajectories, either under natural conditions or in response to environmental change over the long-term, as in the case of the global analysis of seagrass trajectories by Waycott et al. 2009. In this review, information gaps by geographic areas are visualised by plotting locations where data on species presence, meadow size, or both, are available in the region (Figure 5).

There is quite an even spread of sampling sites and a high level of information (species presence and seagrass areal extent) in the Gulf of Tonkin, the Gulf of Thailand, the Eastern Philippines, Lesser Sunda and the continental part of the Andaman Sea Coral Coast ecoregion (see solid points in Figure 5).

Ecoregions that potentially have seagrass habitats but which are data depauperate include:

1. The South China Sea Oceanic Islands, with merely one data point in the Layang-Layang atoll and no meadow area estimates;

2. The Sulawesi Sea/Makassar Strait, with most of the data points clustered on the southwestern and northeastern coastline of Sulawesi, with no meadow area estimates;
3. The Sunda Shelf/Java Sea, especially on the islands of Borneo and Sumatera;

4. The Arafura Sea, which has just one data point, in the Aru group of islands.

Accessibility to seagrass sites influences the distribution of data points in the region, to a certain extent. Some sites are inaccessible to researchers because they are remote or are under territorial dispute. The South China Sea Oceanic Islands, which include the Spratly Islands, have both characteristics: they lie right in the centre of the South China Sea and have been the subject of multiple overlapping maritime claims by the Philippines, Malaysia, Viet Nam, Brunei, Taiwan and the People's Republic of China for more than 50 years. Because they are physically isolated, these sites are natural laboratories for testing ideas about allopatric differentiation in seagrass and seagrassassociated species, and to elucidate seagrass dispersal routes in the region. To take the example of fish larvae in the Spratly Islands, larval drift time and vector current charts indicate that the western Philippines, Taiwan, south-eastern China, Brunei, and Malaysia are direct sink habitats for coral reef fish from the Spratlys (McManus

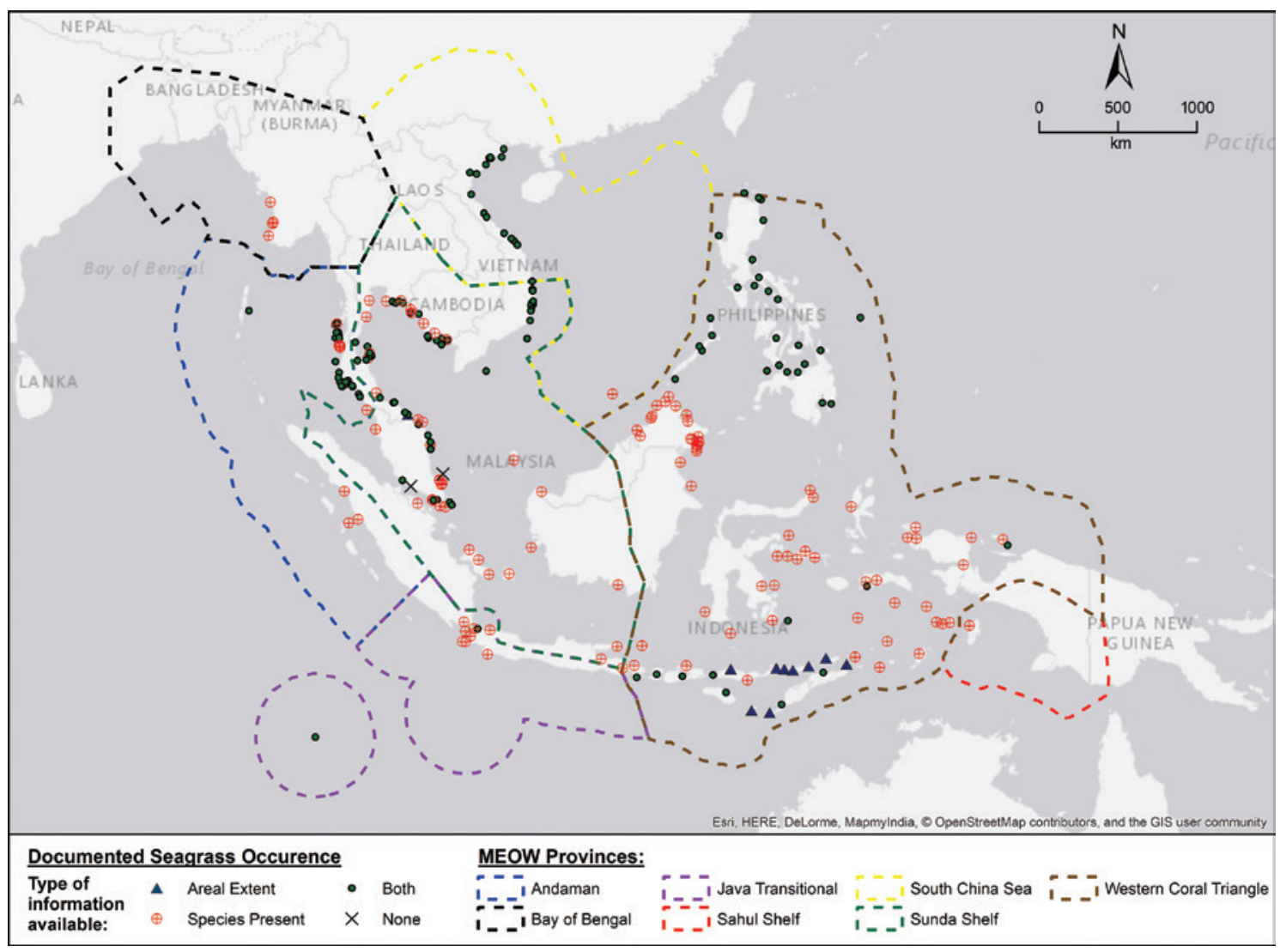

Figure 5: Level of seagrass information available within the Southeast Asian region. 
2017). Long-distance dispersal in seagrasses has also been shown to be possible through seeds, fruits, viviparous seedlings and vegetative fragments, all of which have the capacity to move over hundreds of kilometers in distance (Kendrick et al. 2012). However, if seagrass scientists in the region hope to fill in this data gap, rapid action is necessary because of the amount of recent island-building in this ecoregion as a result of intense territorial claims (Southerland 2016). Island-building often involves sanddredging and land reclamation on shallow coral reefs and in lagoons. To date, two-thirds of currently occupied atolls in the Spratlys have been shown to have proportionally less reef extent than unoccupied atolls, implying the detrimental effects of island-building on reef systems (Asner et al. 2017). Along with these reefs, seagrasses may also be equally damaged before being recorded and studied for science.

Google Earth images of the the Sulawesi Sea/Makassar Strait ecoregion show the presence of soft substrate coastlines, large estuaries, and outlying islands which are often associated with seagrass. Seagrasses appear to be widespread in this ecoregion, and the area of Derawan, east Kalimantan, in particular has been the subject of study (McKinnon et al. 1996, van der Zon 2010). However, the available sources mentioned seagrass in the area in a broad sense, without giving details of locations, full species list, or meadow extent. Similarly, the Sunda Shelf/Java Sea ecoregion has sparse datasets on the Malaysian side of Borneo despite anecdotal evidence for large areas of seagrass along those coastlines (Japar Sidik pers. obs.).
An observation that came up in this effort to review updated seagrass species and meadow information was that these were often categorised according to countries. This is certainly useful from a national point of view, but for seagrass science to be cohesive at the regional level, we need to ensure that information about species and meadow estimates are both sea-specific and countryspecific. In this review, we used MEOW bioregions for this purpose. However, other biogeographic schemes may be just as useful, and we regard the use of bioregions as a starting point for scientists in the region to discuss data and information needs when collaborating on regionalscale studies.

\section{Thematic gaps in knowledge and information}

Seagrass research in Southeast Asia is increasing based on the number of research papers that have been produced in the last decade (Ooi et al. 2011a), and an update of the number of research articles, reports and studies that have been reported in the region has shown a steady increase in research output decade by decade for most countries (Figure 6). However, there are still noticeable gaps in knowledge in Cambodia, and Myanmar, as well as places like East Timor, Brunei, and the Cocos (Keeling) Islands. There is also an increase in the number of research papers, reports, and theses published by authors originating from or based in the country or region itself, which indicates an increase in research interest and capacity of local scientists. There has been an increase in the number of national

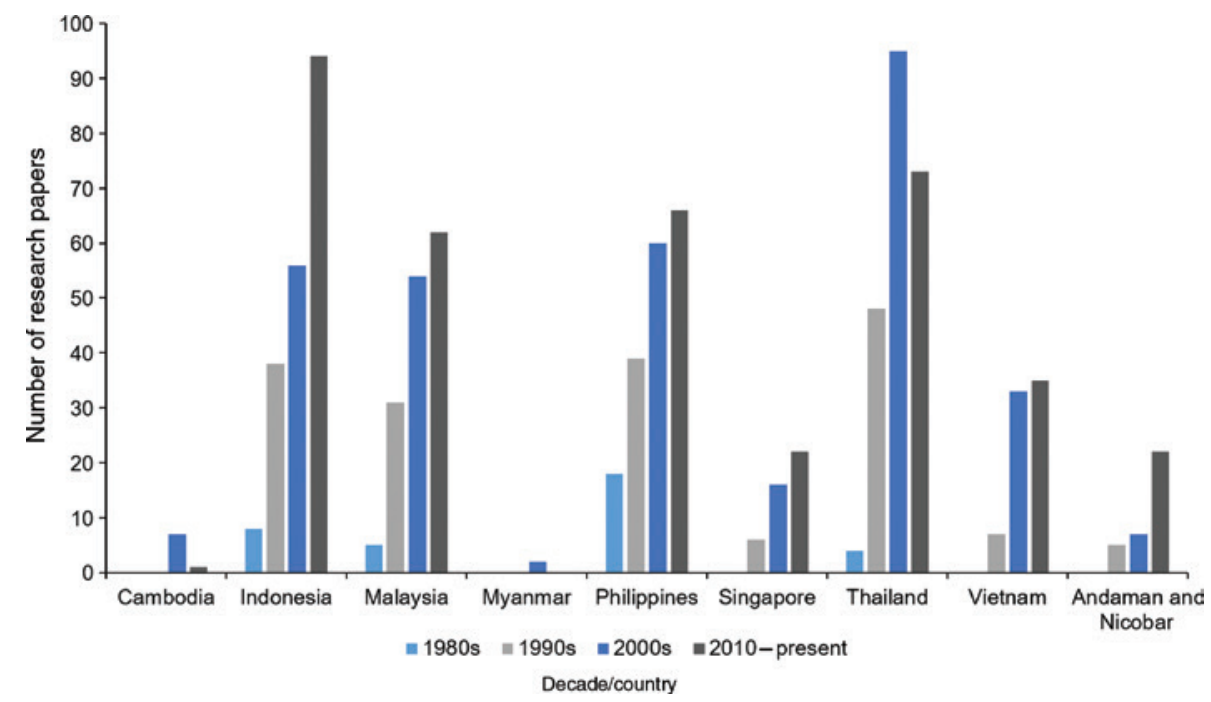

Figure 6: Research output per decade by country/territory.

Numbers based on searches on Web of Science and updated from Ooi et al. (2011a). 
or regional journals being made available online, which has increased the visibility of the research being published, along with academic sharing and networking sites, such as ResearchGate ${ }^{\mathrm{TM}}$ which allows researchers with a verified profile to share their research output - both in journals as well as in other forms, such as reports, posters, conference proceedings, book chapters, etc. - to be shared publicly and directly with the platform's audience.

Taxonomic research continues to be a mainstay of the research efforts in this region, with new species - particularly in the Halophila ovalis species complex (Waycott et al. 2004) - being described (see Kuo 2007, Japar Sidik and Muta Harah 2011, Fortes 2013). However, there is an obvious need for traditional morphological seagrass taxonomy to embrace new methods in the field. There is currently already a Global Initiative to Barcode Seagrass (GIBS) based at the State Herbarium of South Australia and the University of Adelaide (GIBS 2018), and more participation from researchers in the Southeast Asian region may be beneficial for the advancement of seagrass taxonomy.

There is an increasing trend of research output for the region as a whole (Ooi et al. 2011a; Figure 6), and there are some distinct trends in the intensity of work within each thematic research area across the decades (Figure 7). There was a surge in the number of seagrass ecology and environment related research from the 1990s onwards, and this is by far the most productive research area in terms of output. There has also been a progression in this field moving away from purely descriptive to more experimental studies examining interactions and cumulative stressors and anthropogenic impacts of the major causes of seagrass decline such as sedimentation (Cabaço and
Santos 2007, Manzanera et al. 2011, Ooi et al. 2011b, Han et al. 2012), water quality declines and light reduction (Bite et al. 2007, Leoni et al. 2008, Baden et al. 2010, Collier et al. 2011, Yaakub et al. 2014a), changes in temperature (Campbell et al. 2006, Collier and Waycott 2014, Gao et al. 2017), and competition with macroalgae (Davis and Fourqurean 2001, Taplin et al. 2005, Martinez-Luscher and Holmer 2010, Holmer et al. 2011).

New research themes also emerged in the 1990s concerning conservation and management (e.g. Fortes 1991, Kirkman and Kirkman 2002, Unsworth and Cullen 2010), and connectivity of seagrass habitats (e.g. Fortes 1988, Vermaat et al. 2004), likely in response to the trend of habitat loss from the rapid population expansion across Southeast Asia between the mid-90s and the present. There were also some new research areas - such as genetics (e.g. Matsuki et al. 2013, Nakajima et al. 2014, Arriesgado et al. 2015, Hernawan et al. 2017) and blue carbon (e.g. Miyajima et al. 2015, Alongi et al. 2016, Rozaimi et al. 2017) - that have increased in intensity, advancements, and improvements in protocols and methodology. More traditional research areas, such as mapping of areal extent of seagrass habitats, also received a boost in research output with improvements in remote sensing technology, and accessibility of satellite imagery. Continued interest in this field and expansion of research into more remote areas can help improve and continue to address information gaps in areal extent of seagrass meadows in the region, and also start to expand into examining seasonal variation and decline.

Despite the continued increase in research, it is plain to see that a lot of work still needs to be carried out in order to address the gaps in knowledge and information.

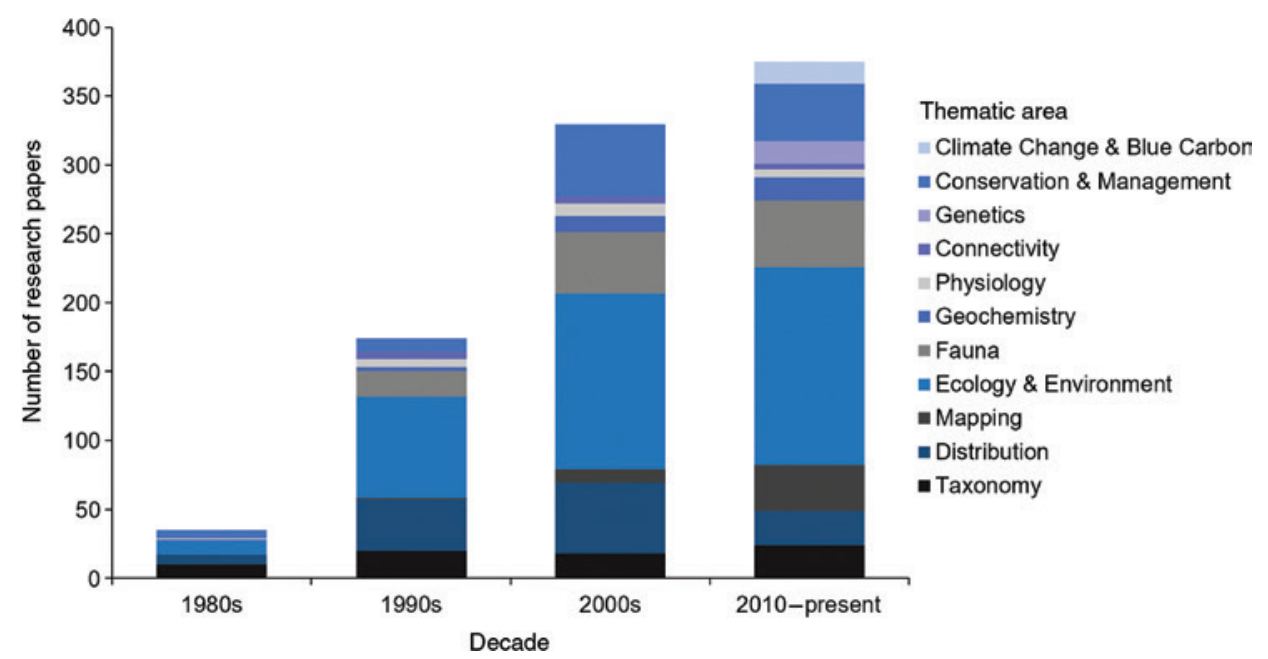

Figure 7: Research output for the Southeast Asian region by thematic area presented as decadal totals. 
For example, there is virtually no social science research examining the social, cultural and economic aspects of human-seagrass interactions, and there is research emerging that points to important relationships between coastal populations and seagrass beds (Cullen-Unsworth et al. 2014). Furthermore, while the significance of seagrass fishery activity has been acknowledged globally (Nordlund et al. 2017), the lack of information on seagrass fishery resources and the flow-on benefits from ecosystem services it provides in the Southeast Asian region is a data gap that needs to be addressed (Unsworth et al. 2009). In Table 4, we suggest the direction for existing and new thematic research areas, as well as potential areas for regional research cooperation.

\section{Paving the way: key challenges for the next decade}

There have been previous articles and reviews on challenges for seagrass conservation in Southeast Asia, and while we do not wish to revisit them, the obstacles to the effective management and conservation of seagrass habitats must be addressed. If the experiences of coral reef and mangrove habitats are any indication, the past half century has taught us that the future of seagrass meadows in SE Asia is bleak, their degradation is expected to continue, despite greater local and region-wide conservation efforts and the promises of programs and projects being implemented and planned. Fortes (2013) addressed some key challenges for seagrass habitats in the context of the Philippines, but these concepts can be extrapolated and are widely applicable to the Southeast Asian region as a whole. We have summarised the six key challenges that are hampering efforts towards the successful management of seagrass habitats in the region in Table 5.

The first three challenges are rooted around the central problem of lack of knowledge, expertise, and information. Expertise in seagrass research and information on tropical seagrass habitats in the region was built on collaborations and partnerships with research partners from outside the region. Actual capacity building and training of researchers in the region seemed to be concentrated in some institutions, with little to no information sharing beyond those institutions (Table 5; Challenge \#1). Where seagrass research was carried out by researchers outside the centers of knowledge, the work tends to be highly descriptive, which is likely fuelled by the lack of training, expertise, and resources (Table 5; Challenge \#2). This lack of access to information and training, especially in basic methods, then exacerbates the problem of lack of basic knowledge of seagrass meadows in Southeast Asia (Table 5; Challenge \#3), which results in a paucity of basic information such as spatial extent, species composition, and cover. To overcome these challenges requires a concerted and multipronged approach, and must come from researchers who are based in Southeast Asia themselves. Forming a network of scientists working in the region (even informally) builds a collaborative and supportive research and knowledge sharing network. Training workshops for young researchers and inter-institution collaboration and exchanges should be encouraged. Knowledge sharing can also avoid duplication of work and sharing of resources and equipment, and the institutional diversity could also put researchers in a better and more competitive position when it comes to funding opportunities.

The next three challenges are related to policy-making, and management of natural resources. While management efforts have been initiated at various sites across the region, these have largely focused on remedial or curative measures, and do not address the root problems (Table 5; Challenge \#4). The causes of seagrass decline in Southeast Asia are well documented, and many of these are due to anthropogenic impacts related to coastal development. These impacts need to be addressed in order to stem further deterioriation of seagrass meadows across the region. Although attempts are occasionally made to undertake seagrass relocation and restoration, these are often not the most cost-effective solution as success rates are quite low despite a large input of effort and funds (van Katwijk et al. 2015). These ineffective solutions are also often compounded by the lack of effective linkages between science, government, and private sectors, leading to poor management and conservation actions taken. There is currently a big gap or disconnect between seagrass science, policy, and practice (Fortes 2018).

In turn, these management and conservation actions, or environmental laws are not always adequately enforced or implemented (Table 5; Challenge \#5). It is especially difficult to slow down coastal development in the developing world, and even more challenging to justify conservation of natural habitats over economic growth. The prioritisation of economic growth means that environmental laws are not always put in place, with no proper safeguards against habitat degradation and destruction. Where environmental laws exists, they are not always effectively enforced as enforcement agents sometimes lack sufficient resources or authority to carry out their duties. Designation of marine parks is also often inadequate, with fishing, aquaculture, or other anthropogenic activities that impact 


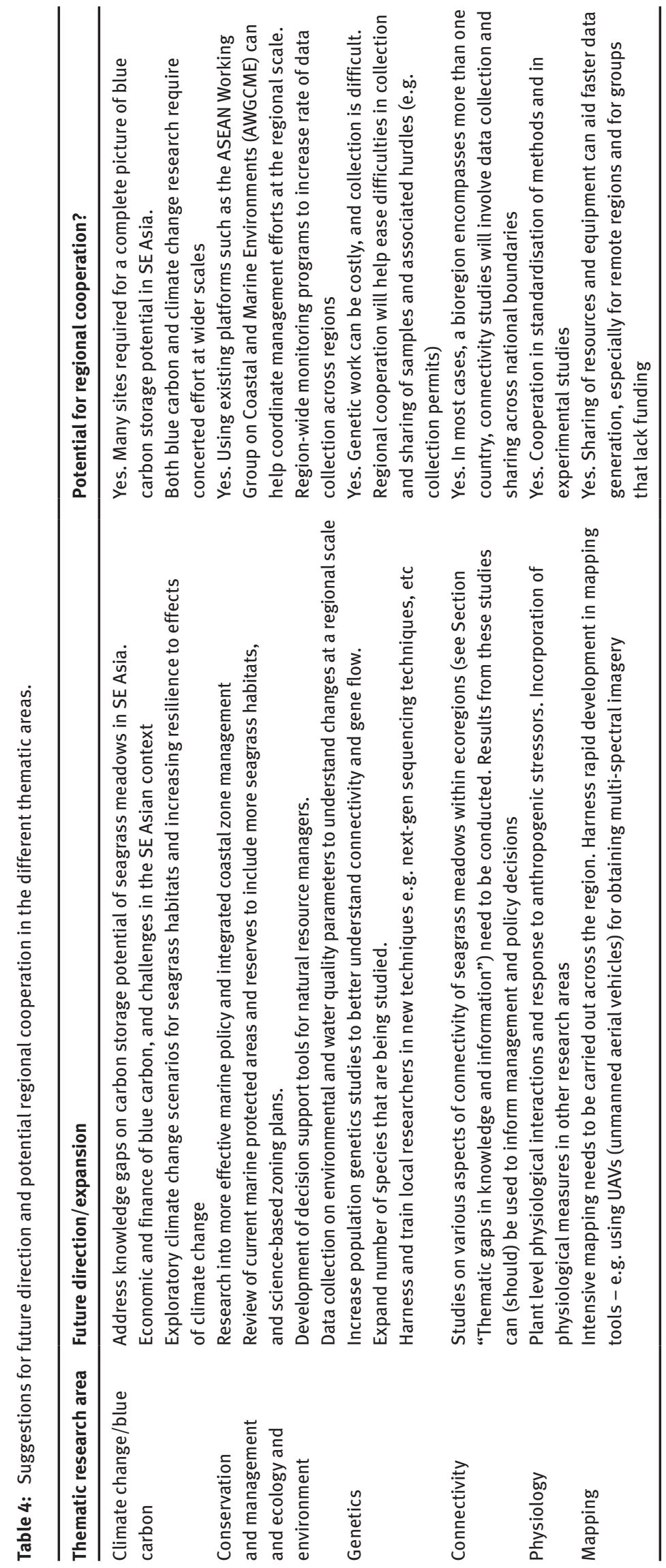




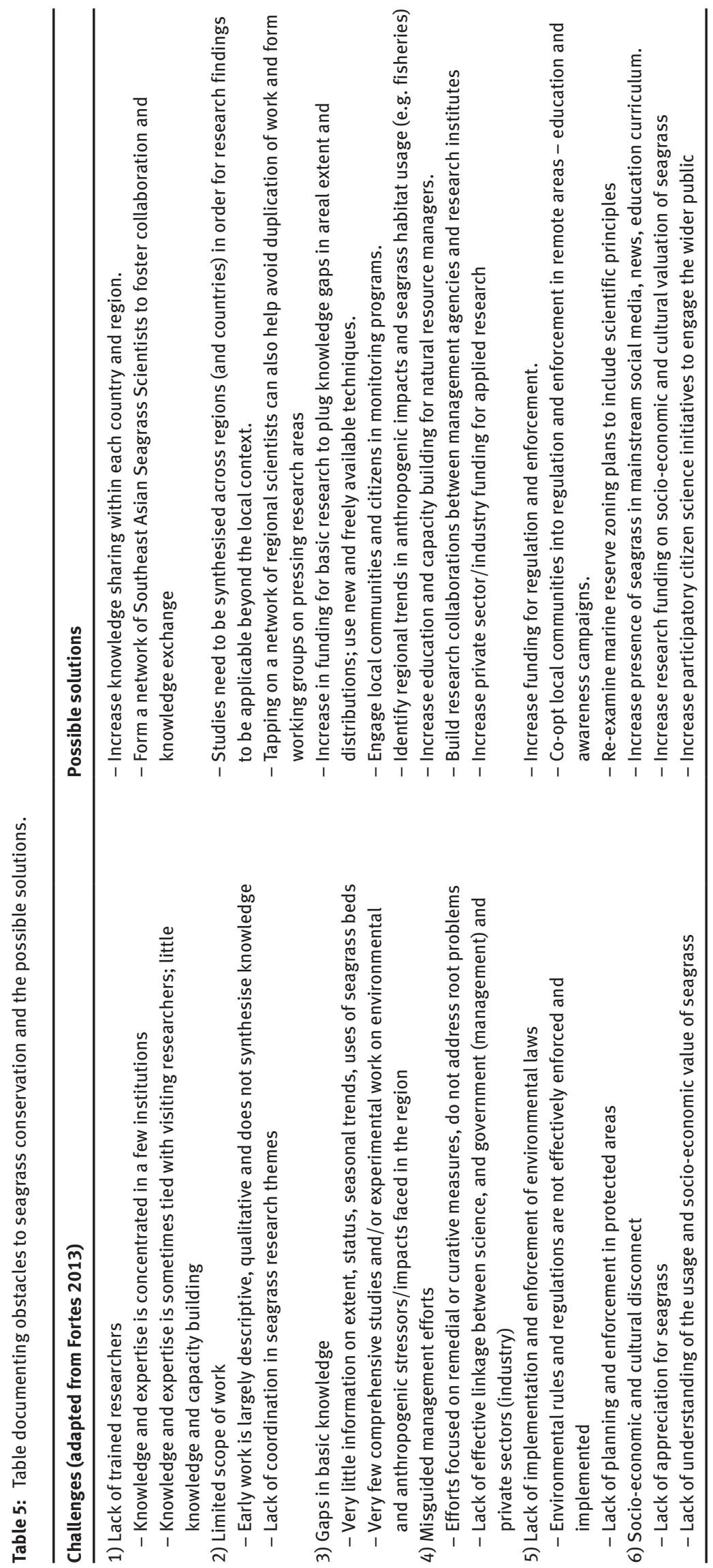


seagrass meadows continuing to take place (e.g. Guimarães et al. 2012).

One of the major difficulties surrounding implentation and enforcement of enviromental laws is often resistance from the local seafaring communities (Bennett and Dearden 2014). This social-economic and cultural disconnect is the last challenge facing seagrass conservation (Table 5; Challenge \#6). Seagrass ecosystems have been reported to be one of the least charismatic of coastal ecosystems, especially when compared to coral reefs, and this lack of charisma often translates into lack of attention, research, and conservation action (Duarte et al. 2008). To counter this, and to bring seagrass into the collective consciousness of society and government, active steps need to be taken by seagrass scientists to reach across the divide to educators, managers, and the wider public, in order to garner support for seagrass science and conservation. One of the ways of achieving this aim is to introduce natural heritage education into the school curriculum (Table 5). The development of natural heritage curriculum could potentially inculcate greater conservation values from an early age, leading to greater interest and awareness of seagrass ecosystems in the future, as well as participation in voluntary citizen science programs. The value of citizen science is widely acknowledged, with the United Nations
Environment Programme emphasising the importance of public participation towards sustainability (UNEP 1995). Such initiatives provide long-term monitoring data of seagrass meadows at a much lower cost, allowing research funding to be directed at other research avenues (Theil et al. 2014). A successful example of a long-term citizen science monitoring program in Southeast Asia is TeamSeaGrass (Yaakub et al. 2014b). TeamSeaGrass is part of the Seagrass-Watch Network and the data collected by volunteers have contributed towards scientific publications (Yaakub et al. 2014c, McKenzie et al. 2016), and been shared with managers from the National Parks Board (NParks) in Singapore.

Moving forward, a road map for seagrass conservation and research in Southeast Asia is proposed (Figure 8). The road map incorporates the main challenges facing seagrass conservation as identified above (Table 5), and proposes solutions that have the potential to solve several problems and provide the proper approach to face these challenges at the same time. Three main outcomes are proposed for the conservation and management of seagrass in Southeast Asia - (1) moving towards knowledge-based decision making, (2) understanding the socio-cultural-economics of seagrass ecosystems, and (3) increase seagrass awareness and understanding. As already mentioned, several

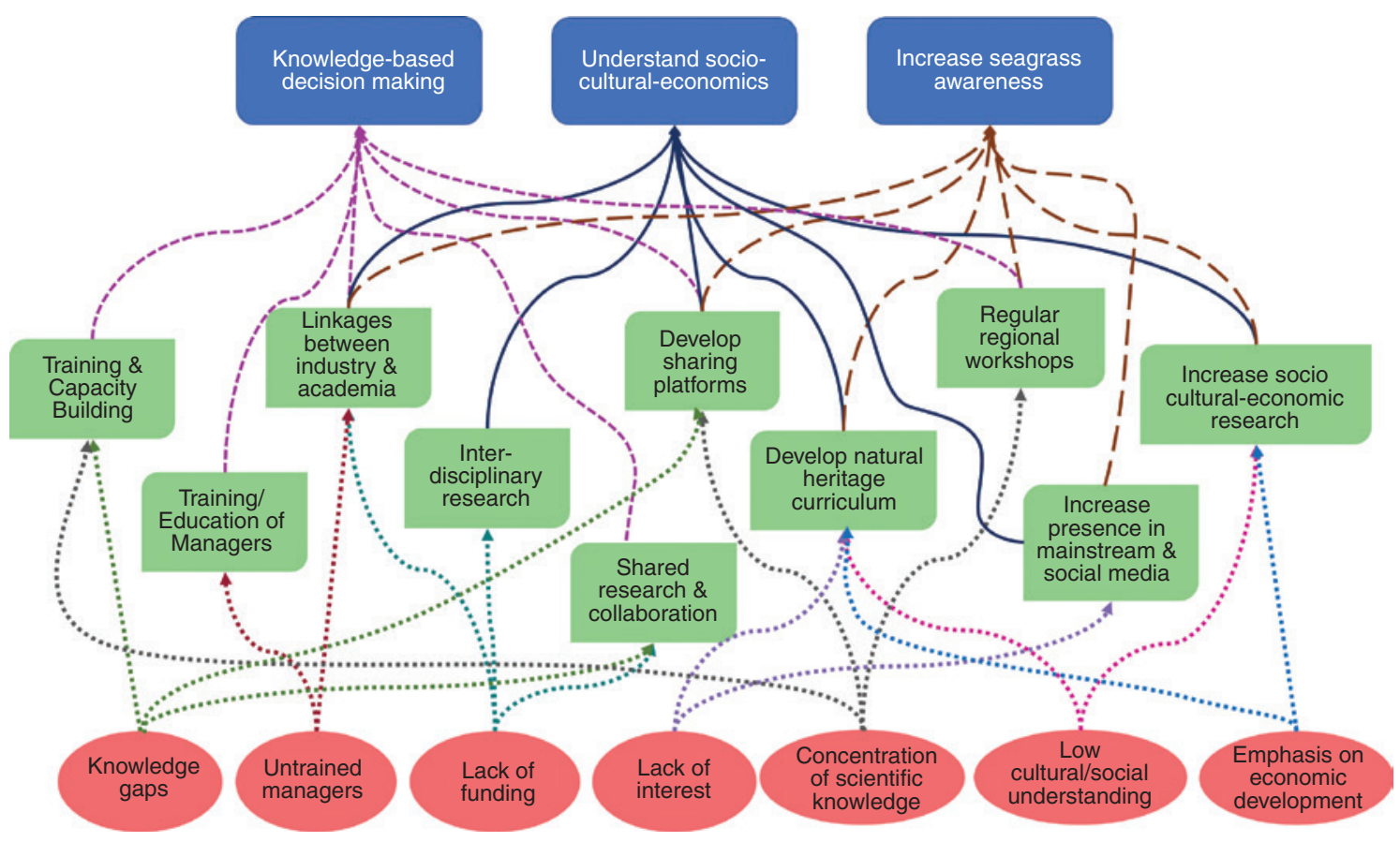

Figure 8: Roadmap for addressing conservation challenges facing seagrass in the Southeast Asian region.

Challenges can have multiple solutions and these solutions can contribute to a final aim. The challenges are listed at the bottom of the figure in red ovals and the final aims are at the top of the figure in blue boxes. Intermediate solutions are presented in the middle in green boxes. Dotted lines represent linkages betweeen the challenges and the intermediate solutions, with each dotted line colour coded specific to a challenge. Intermediate solutions that contribute to a final aim are joined by dashed and solid lines and colour coded. 
challenges impeding seagrass conservation in research are interconnected. For example, knowledge gaps in the region is itself a challenge, but is also a result of other problems such as the lack of funding or lack of interest. Similarly, the solutions to these challenges are also connected. This interconnectedness allows conservation managers and other stakeholders to identify the most appropriate action to take immediately, and to prioritise conservation and management accordingly based on the specific needs of each area. This multipronged approach towards conservation and management of seagrass meadows in Southeast Asia is illustrated in Figure 8.

\section{A roadmap for seagrass conservation and research in Southeast Asia}

An example of sharing platforms would be the International Seagrasss Biology Workshop (ISBW). The ISBW series is a meeting of research scientists, students, and coastal environment managers focusing on global seagrass issues, improving seagrass knowledge, developing networks and advocating seagrass protection or conservation. Twelve ISBWs have been held and each followed individual themes reflecting both a geographical or institutional interest, and current trends in seagrass research as new knowledge and techniques became available (Coles et al. 2014). The 12th ISBW held in Nant Gwrtheyrn in North Wales focused on securing a future for seagrass. The 13th ISBW, to be held in Singapore in June 2018, will have a theme of "Translating Science into Action", and will focus on current developments in seagrass science and how it can be effectively developed into actions, programs, and policies that will aid in seagrass conservation and management. These outcomes are important, not just for the Southeast Asian region, but globally as well.

Regionally, there is the option of leveraging on existing platforms to foster sharing and cooperation, such as the Association of Southeast Asian Nations (ASEAN) Cooperation on Environment. This regional organisation holds nature conservation and biodiversity, and the coastal and marine environment as two of its seven strategic priorities (ASEAN Cooperation on Environment 2017). Getting seagrass conservation on the ASEAN environmental agenda would be a big boost in terms of fostering cooperation, collaboration, and knowledge sharing in the region. This in itself, will be an uphill task, especially since there are competing environmental issues, such as transboundary haze, which are more visible and seemingly have wider regional urgency. There are also other ASEAN-related bodies, such as the ASEAN Center for Biodiversity, which could be a smaller and more manageable platform to launch the seagrass conservation and management agenda for the region.

It is likely that the degradation of seagrass ecosystems is expected to continue, despite greater local and regionwide conservation efforts and the promises of programs and projects being implemented and planned. At present, there appear only two likely options left for us: status quo or "business as usual", wherein coastal development are intensified, but with almost complete disregard of relevant scientific knowledge and pertinent laws; or protect and enhance what remains of the ecosystem, wherein people are given the opportunity to conserve and enjoy them for themselves and the future generations. It is easy to argue in favour of a combination of these approaches, but as the past years have shown, this has been easier said than done. To our knowledge, success along this line in the region has been insignificant - in both temporal and spatial magnitude and scale - in relation to the total area of coastal space utilised and the amount of resources spent. There is an increasing likelihood that coastal environmental change will create a need for adjustments of established ecosystems on spatial and temporal scales that are unprecedented in SE Asian history. Hopefully, these adjustments are not compromises to the detriment of seagrass ecosystems.

Sound conservation and management of our seagrass ecosystems can be realised. Basic human survival as well as robust national and global socioeconomic arguments underline the compelling need for the effort. The specific interventions in improving seagrass management in the world have been spelled out even as early as the 1990s (Fortes 1991, UNEP SCS/SAP 1999) and more recently by UNEP (2012), but even with these, a secure future for the region's seagrass resources seemingly remains out of sight. Trajectories toward seagrass loss can be reversed if and when all concerned stakeholders contribute positively to the effort in reversing current coastal ecosystem degradation trends. In order to sustain the benefits we all derive from these natural assets, substantial commitments and investments must collectively be made by communities, scientists, local government units, national government agencies, and assisting organisations to effect a change from the current self-destructive course to one of conservation and sustainable use. Indeed, a transdisciplinary approach is required, with each proposed step undertaken in a holistic manner and not separately or compartmentalised. There is a great opportunity and compelling grounds for regional collaboration and cooperation to tackle the issue of seagrass conservation. It would be a tragedy to let it slip. 


\section{References}

Alongi, D.M., D. Murdiyarso, J.W. Fourqurean, J.B. Kauffman, A. Hutahaean, S. Crooks, C.E. Lovelock, J. Howard, D. Herr, M.D. Fortes, E. Pigeon and T. Wagey. 2016. Indonesia's blue carbon: a globaly significant and vulnerable sink for seagrass and mangrove carbon. Wetlands. Ecol. Manage. 24: 3-13.

Anscelly, A.A. 2014. The effect of Coastal Development on Seagrass Spatial Distribution of Pulau Pinang Waters (Master's Thesis). Universiti Sains Malaysia, Pulau Pinang, Penang, Malaysia.

Arifin, Z. 2004. Local Millenium Ecosystem Assessment: Condition and trend of the Greater Jakarta Bay Ecosystem. Report submitted to: Assistant Deputy for Coastal and Marine Ecosystem, The Mintry of Environment, Republic of Indonesia.

Arriesgado, D.M., H. Kurokochi, Y. Najajima, Y. Matsuki, W.H. Uy, M.D. Fortes, W.L. Campos, K. Nadaoka and C. Lian. 2015. Genetic diversity and structure of the tropical seagrass Cymodocea serrulata spanning its cenral diversity hotspot and range edge. Aqua. Ecol. 49: 357-372.

ASEAN Cooperation on Environment. 2017. ASEAN Cooperation on Environment - At a glance. Jakarta, ASEAN Secretariat, November 2017. http://environment.asean.org/wp-content/ uploads/2018/02/ASEAN-Cooperation-on-Environment-At-AGlance-Dec-2017.pdf (Accessed 13 April 2018).

Asner, G.P., R.E. Martin, J. Mascaro, R. Williams and D. Boyd, D. 2017. Coral reef atoll assessment in the South China Sea using Planet Dove satellites. Remote. Sens. Ecol. Conserv. 3: 57-65.

Baden, S., C. Boström, S. Tobiasson, H. Arponen and P.O. Moksnes. 2010. Relative importance of trophic interactions and nutrient enrichment in seagrass ecosystems: a broad-scale field experiment in the Baltic - Skagerrak area. Limnol. Oceanogr. 55: $1435-1448$

Benjamin, K.J., D.I. Walker, A.J. McComb and J. Kuo. 1999. Structural response of marine and estuarine plants of $\mathrm{Hal}$ ophila ovalis (R-Br.) Hook. f. to long-term hyposalinity. Aquat. Bot. 64: 1-17.

Bennett, N.J. and P. Dearden. 2014. Why local people do not support conservation: community perceptions of marine protected area livelihood impacts, governance and management in Thailand. Mar. Pol. 44: 107-116.

Bite, J.S., S.J. Campbell, L.J. McKenzie and R.G. Coles. 2007. Chlorophyll fluorescence measures of seagrassess Halophila ovalis and Zostera capricorni reveal differences in response to experiment shading. Mar. Biol. 152: 405-414.

BOBLME. 2015. The Bay of Bengal: an overview of a large marine ecosystem. BOBLME, Phuket, Thailand. pp. 36.

Bowen, B.W., M.R. Gaither, J.D. DiBattista, M. lacchei, K.R. Andrews, W.S. Grant, R.J. Toonen and J.C. Briggs. 2016. Comparative phylogeography of the ocean planet. Proc. Natl. Acad. Sci. USA 113: 7962-7969.

Cabaço, S. and R. Santos. 2007. Effects of burial and erosion on the seagrass Zostera noltii. J. Exp. Mar. Biol. Ecol. 340: 204-212.

Calumpong, H.P., E.J. Stacion, J.R. Lucañas and P.L. Cadiz. 2010. Halophila tricostata Greenway (Hydrocharitaceae): an unreported seagrass from the Philippines. Poster presented at the World Seagrass Conference, Phuket, Thailand. November 20-25.

Campbell, S.J., L.J. McKenzie and S.P. Kerville. 2006. Photosynthetic responses of seven tropical seagrasses to elevated seawater temperature. J. Exp. Mar. Biol. Ecol. 330: 455-468.
Carpenter, K.E. and V.G. Springer. 2005. The center of the center of marine shore fish biodiversity: the Philippine Islands. Environ. Biol. Fish. 72: 467-480.

Chou, L. 2014. Climate change impcts on Southeast Asia's marine biodiversity. The Asian Conference on Sustainability, Energy and the Environment. Official Conference Proceedings 05777, The International Academic Forum, Nagoya, Japan.

Coles, R., F. Short, M.D. Fortes and J. Kuo. 2014. Twenty years of seagrass networking and advancing seagrass science: the International Seagrass Biology Workshop Series. Pac. Conserv. Biol. 20: 8-16.

Collier, C.J. and M. Waycott. 2014. Temperature extremes reduce seagrass growth and induce mortality. Mar. Pollut. Bull. 83: 483-490.

Collier, C.J., S. Uthicke, M. Waycott. 2011. Thermal tolerance of two seagrass species at contrasting light levels: implications for future distribution in the Great Barrier Reef. Limnol. Oceanogr. 56: $2200-2210$

Cullen-Unsworth, L.C. and R. Unsworth. 2013. Seagrass meadows, ecosystem services, and sustainability. Environ. Sci. Pol. Sust. Dev. 55: 14-28.

Cullen-Unsworth, L.C., L.M. Nordlund, J. Paddock, S. Baker, L.J. McKenzie and R.K. Unsworth. 2014. Seagrass meadows globally as a coupled social-ecological system: implications for human wellbeing. Mar. Pollut. Bull. 83: 387-397.

Davis, B.C. and J.W. Fourqurean. 2001. Competition between the tropical alga, Halimeda incrassata, and the seagrass, Thalassia testudinum. Aquat. Bot. 71: 217-232.

de longh, H.H., B.J. Wenno and E. Meelis. 1995. Seagrass distribution and seasonal biomass changes in relation to dugong grazing in the Moluccas, East Indonesia. Aquat. Bot. 50: 1-19.

den Hartog, C. 1970. The seagrasses of the word. North Holland Publishing Co., Amsterdam. pp. 275.

den Hartog, C. and J. Kuo. 2007. Taxonomy and biogeography of seagrasses. In: (A.W.D Larkum, R.T. Orth and C.M. Duarte, eds.) Seagrasses: biology, ecology and conservation. Springer, Dordrecht. pp. 1-23.

Douven. W.J. A M., J.J.G. Burrman and W. Kiswaran. 2003. Spatial information for coastal zone management: the example of the Banten Bay seagrass ecosystem, Indonesia. Ocean. Coast. Manage. 46: 615-634.

Duarte, C.M., W.D. Dennison, R.J.W. Orth and T.J.B. Carruthers. 2008. The charisma of coastal ecosystems: addressing the imbalance. Estuar. Coast. 33: 233-238.

Fitrian, T., A. Kusnadi and R.N. Persilette. 2017. Seagrass community structure of Tayando-Tam Island, Southeast Moluccas, Indonesia. Biodiversitas. 18: 788-794.

Flanders Marine Institute. 2016. Maritime Boundaries Geodatabase: Territorial Seas (12NM), version 1. Available online at http:// www.marineregions.org/ https://doi.org/10.14284/243. Consulted on 2017-11-26.

Fortes, M.D. 1988. Indo West Pacific affinities of Philippine seagrasses. Bot. Mar. 31: 237-242.

Fortes, M.D. 1989. Seagrasses: a resource unknown in the ASEAN region. ICLARM education series, International Centre for Living Aquatic Resources Management, Manila, Philippines. pp. 46.

Fortes, M.D. 1991. Seagrass mangrove ecosystems management: a key to marine coastal conservation in the ASEAN region. Mar. Pollut. Bull. 23: 113116. 
Fortes, M.D. 1995. Seagrasses of East Asia: Environmental and Management Perspectives. RCU/EAS Technical Report Series No. 6, United Nations Environment Programme, Bangkok, Thailand. $75 \mathrm{pp}$.

Fortes, M.D. 2013. A review: biodiversity, distribution and conservation of philippine seagrasses. Philippine. J. Sci. 142: 95-111.

Fortes, M.D. 2018. Seagrass ecosystem conservation in Southeast Asia needs to link science to policy and practice. Ocean. Coast. Manage (in press). https://doi.org/10.1016/j.ocecoaman.2018.01.028.

Fourqurean, J.W., C.M. Duarte, H. Kennedy, N. Marbà, M. Holmer, M.A. Mateo, E.T. Apostolaki, G.A. Kendrick, D. Krause-Jensen, K.J. McGlathery and O. Serrano. 2012. Seagrass ecosystems as a globally significant carbon stock. Nat. Geosci. 5: 505-509.

Gao, Y., J. Fang, M. Du, J. Fang, W. Jiang and Z. Jiang. 2017. Response of the eelgrass (Zostera marina L.) to the combined effects of high temperatures and the herbicide, atrazine. Aquat. Bot. 142: 41-47.

GIBS. 2018. Global Initiative to Barcode Seagrass (http://barcoding. seagrassonline.org/; Accessed 14 April 2018).

Greenway, M. 1979. Halophila tricostata (Hydrocharitaceae), a new species of seagrass from the Great Barrier Reef region. Aquat. Bot. 7: 67-70.

Guimarães, M.H.M.E., A.H. Cunha, R.L. Nzinga and J.F. Marques. 2012. The distribution of seagrass (Zostera noltii) in the Ria Formosa lagoon system and the implications of clam farming on its conservation. J. Nat. Conserv. 20: 30-40.

Han, Q.Y., T.J. Bouma, F.G. Brun, W. Suykerbuyk and M.M. Van Katwijk. 2012. Resilience of Zostera noltii to burial or erosion disturbances. Mar. Ecol. Prog. Ser. 449: 133-143.

Hernawan, U.E., K.J. Dijk, G.A., Kendrick, M. Feng, E. Biffin, P.S. Lavery and K. McMahon. 2017. Historical processes and contemporary ocean currents drive genetic structure in the seagrass Thalassia hemprichii in the Indo-Australian Archipelago. Mol. Ecol. 26: 1008-1021.

Hobbs, J.P.A., A.J. Frisch, J. Hender and J.J. Gilligan. 2007. Long-distance oceanic movement of a solitary dugong (Dugong dugon) to the Cocos (Keeling) Islands. Aquat. Mamm. 33: 175-178.

Holmer, M., P. Wirachwong and M.S. Thomsen. 2011. Negative effects of stress-resistant drift algae and high temperature on a small ephemeral seagrass species. Mar. Biol. 158: 297309.

Hossain, M.S., B. Japar Sidik, Z. Mutu Harah and M. Hashim. 2015a. Landsat image enhancement techniques for subtidal and intertidal seagrass detection and distribution mapping in the coastal waters of Sungai Pulai estuary, Malaysia. Coast. Mar. Sci. 38: 27-41.

Hossain, M.S., B. Japar Sidik, Z. Mutu Harah and M. Hasim. 2015b. Application of Landsat images to seagrass areal cover change analysis for Lawas, Terengganu and Kelantan of Malaysia. Cont. Shelf. Res. 110: 124-148.

Ibrahim, H.M. and K. Nazery. 2007. Growing shipping traffic in the Strait of Malacca: some reflections on the environmental impact In: Global Maritime and Intermodal Logistics Conference, Singapore.

Jaaman, S.A., E.I. Ahmad-Kamil, J. Bali, K. Redzwan, L. Rajamani, L.S. Ponnampalam, S.A.K. Syed Abdullah, M.S. Mohd Lazim and A. Azlina. 2011. UNEP CMS Dugong Project Country Report 2011 - Malaysia. Working paper of the UNEP/CMS Southeast Asia Sub-Regional Meeting on Dugongs and Workshop on
Developing Standard Analysis Protocols for Dugong Questionnaire Survey Project Data for Southeast Asia Region, Lawas, Sarawak, Malaysia, 27-29 July 2011.

Jagtap, T.G., D.S. Komarpant and R.S. Rodrigues. 2003. Status of a seagrass ecosystem: an ecologically sensitive wetland habitat from India. Wetlands 23: 161-170.

Japar Sidik, B. and Z. Muta Harah. 2003. The seagrasses of Malaysia. In: World atlas of seagrasses. UNEP World Conservation Monitoring Centre. University of California Press, Berkeley, USA. pp. 152-160.

Japar Sidik, B. and Z. Muta Harah. 2011. Seagrasses in Malaysia. In: (H. Ogawa, B. Japar Sidik and Z. Muta Harah, eds.) Seagrasses: resource status and trends in Indonesia, Japan, Malaysia, Thailand and Vietnam. Seizando-Shoten Publishing Co., Ltd., Tokyo. pp. 22-37.

Japar Sidik, B., W.S. Muta Harah, A.M. Pauzi and S. Madhavan, S. 1999. Halodule species from Malaysia - distribution and morphological variation. Aquat. Bot. 65: 33-45.

Japar Sidik, B., Z. Muta Harah, M.L. Fakhrulddin, M.S. Khairul Anwar and A. Arshad. 2010. Growth performance of Malaysian spoongrass, Halophila ovalis (R. Br.) Hooker $f$. under different substrate, salinity and light regime. Coast. Mar. Sci. 34: 103-107.

Jones, G.W. 2013. The population of Southeast Asia. ARI Working Paper, No. 198, http://www.ari.nus.edu.sg/wps/wps13_196.pdf.

Kamal, E., B. Japar Sidik and Z. Muta Hara. 2010. New records of seagrass flora in Air Bangis, West Sumatera. Jurnal. Natur. Indonesia. 13: 77-81.

Kawaroe, M., A.H. Nugraha, Juraij and I.A. Tasabaramo. 2016. Seagrass biodiversity at three marine ecoregions of Indonesia: Sunda Shelf, Sulawesi Sea, and Banda Sea. Biodiversitas. 17: 585-591.

Kendrick, G.A., M. Waycott, T. Carruthers, M. Cambridge, R. Hovey, S. Krauss, P. Lavery, D. Les, R. Lowe, O. Mascaró i Vidal, J.L.S. Ooi, R.J. Orth, D. Rivers, L. Ruiz-Montoya, E.A. Sinclair, J. Statton, K. Van Dijk and J. Verduin. 2012. The central role of dispersal in the maintenance and persistence of seagrass populations. BioScience 62: 56-65.

Kim, Y.K., S.H. Kim, J.M. Yi, C. Kang, F. Short and K. Lee. 2017. Genetic identification and evolutionary trends of the seagrass Halophila nipponica in temperate coastal waters of Korea. PLoS One 12: e1077772.

Kirkman, H. and J.A. Kirkman. 2002. The management of seagrasses in Southeast Asia. Bull. Mar. Sci. 71: 1379-1390.

Kuo, J. 2000. Taxonomic notes on Halophila minor and Halophila ovata. Biol. Mar. Medit. 7: 79-82.

Kuo, J. 2007. New monoecious seagrass of Halophila sulawesii (Hydrocharitaceae) from Indonesia. Aquat. Bot. 87: 171-175.

Kuo, J., Z. Kanamoto, H. lizumi and H. Mukai. 2006. Seagrasses of the genus Halophila Thouars (Hydrocharitaceae) from Japan. Acta. Phytotax. Geobot. 57i: 129-154.

Kuriandewa, T.E. and I.H. Supriyadi. 2006. Seagrass mapping in East Bintan coastal area, Riau Archipelago, Indonesia. Coast. Mar. Sci. 30: 154-161.

Lamit, N., Y. Tanaka and H.M.B.A. Majid. 2017. Seagrass diversity in Brunei Darussalam: first records of three species. Scientia Bruneiana. 16: 48-52.

Leoni, V., A. Vela, V. Pasqualini, C. Pergent-Martini and G. Pergent. 2008. Effects of experimental reduction of light and nutrient enrichments ( $\mathrm{N}$ and $\mathrm{P}$ ) on seagrasses: a review. Aquat. Conserv. 18: 202-220. 
Luong, C.V., N.V. Thao, T. Komatsu, N.D. Ve and D.D. Tien. 2012. Status and threats on seagrass beds using GIS in Vietnam. In Proc. SPIE - Int. Soc. Opt. Eng. 8525: 12.

Manzanera, M., T. Alcoverro, F. Tomas and J. Romero. 2011. Response of Posidonia oceanica to burial dynamics. Mar. Ecol. Prog. Ser. 423: 47-56.

Martinez-Luscher, J. and M. Holmer. 2010. Potential effects of the invasive species Gracilaris vermiculophylla on Zostera marina metabolism and survival. Mar. Environ. Res. 69: 345-349.

Matsuki, Y., A. Takahashi, Y. Nakajima, C. Lian, M.D. Fortes, W.H. Uy, W.L. Campos, M. Nakaoka and K. Nadaoka. 2013. Development of mocrosaellite markers in a tropical seagrass Syringodium isoetifolium (Cymodoceacea). Conserv. Genet. Resour. 5: 715-717.

McGlathery, K.J., K. Sundbäck and I.C. Anderson. 2007. Eutrophication in shallow coastal bays and lagoons: the role of plants in the coastal filter. Mar. Ecol. Prog. Ser. 348: 1-18.

McKenzie, L.J., S.M. Yaakub, R. Tan, J. Seymour and R. Yoshida. 2016. Seagrass habitats of Singapore: environmental drivers and key processes. Raff. Bull. Zool. Supp. 34: 60-77.

McKinnon, K., G. Hatta, H. Halim and A. Mangalik. 1996. Ecology of Kalimantan: Indonesian Borneo. Periplus Editions (HK) Ltd.

McManus, J.W. 2017. Offshore Coral Reef Damage, Overfishing, and Paths to Peace in the South China Sea. Int. J. Mar. Coast. Law. 32: 199-237.

Mintje, W. 2017. Social-ecological system in seagrass ecosystem management at Kotania Bay Waters, Western Seram, Indonesia. IOP Conf. Ser.: Earth Environ. Sci. 89: 012023.

Miyajima, T., M. Hori, M. Hamaguchi, H. Shimabukuro, H. Adachi, H. Yamano and M. Nakaoka. 2015. Geographic variability in organic carbon stock and accumulation rate in sediments of East and Southeast Asian seagrass meadows. Global. Biogeochem. Cy. 29: 397-415.

Mokhzani, Z. 2004. Strategic value of the Malacca Strait. Maritime Institute of Malaysia (MIMA).

Mukai, H. 1993. Biogeography of the tropical seagrasses in the western Pacific. Tropical Seagrass Ecosystems; Structure and Dynamics in the Indo-West Pacific. Aust. J. Mar. Freshwat. Res. 44: 1-17.

Nakajima, Y., Y. Matsuki, C. Lian, M.D. Fortes, W.H. Uy, W.L. Campos, M. Nakaoka and K. Nadaoka. 2014. The Kuroshio Current influences genetic diversity and population genetic structure of a tropical seagrass, Enhalus acoroides. Mol. Ecol. 23: 6029-6033.

Neinhuis, P.J., J. Coosen and W. Kiswara. 1989. Community structure and bioimass distribution of seagrasses and macrofauna in the Flores Sea, Indonesia. Netherlands J. Sea. Res. 23: 197-214.

Nguyen, V.X., L. Holzmeyer and J. Papenbrock. 2013. New record of the seagrass species Halophila major (Zoll.) Miquel in Vietnam: evidence from leaf morphology and ITS analysis. Bot. Mar. 56: 313-321.

Nguyen, V.X., M. Detcharoen, P. Tuntiprapas, U. Soe-Htun, B. Japar Sidik, Z. Muta Harah, A. Prathep and J. Papenbrock. 2014. Genetic species identification and population structure of Halophila (Hydrocharitaceae) from the Western Pacific to the Eastern Indian Ocean. BMC Evol. Biol. 14: 92.

Nordlund, L.M., R.K. Unsworth, M. Gullström and L.C. CullenUnsworth. 2017. Global significance of seagrass fishery activity. Fish Fish. 19: 1-14.

Novak, A.B., E. Hines, D. Kwan, L.L. Par, M.T. Tun, H. Win and F.T. Short. 2009. Revised ranges of seagrass species in the Myeik Archipelago, Myanmar. Aquat. Bot. 91: 250-252.
Ooi, J.L.S., G.A. Kendrick, K.P. Van Viel and Y.A. Affendi. 2011a. Knowledge gaps in tropical Southeast Asian seagrass systems. Estuar. Coast. Shelf. Sci. 92: 118-131.

Ooi, J.L.S., G.A. Kendrick and K.P. Van Niel. 2011b. Effects of sediment burial on tropical ruderal seagrasses are moderated by clonal integration. Cont. Shelf. Res. 31: 1945-1954.

Ooi, J.L.S., K.P. Van Niel, G.A. Kendrick and K.W. Holmes. 2014. Spatial structure of seagrass suggests that size-dependent plant traits have a strong influence on the distribution and maintenance of tropical multispecies meadows. PLoS One 9: e86782.

Patty, S.I. 2016. Mapping the condition of seagrass beds in TernateTidore waters and surrounding areas. J. Ilmiah Platax. 4: 9-18.

Phillips, R.C. 1967. On species of seagrass, Halodule, in Florida. Bull. Mar. Sci. 17: 672-676.

Poovachiranon, S., K. Adulyanukosol, P. Saelim, A. Charoenpornwattana, C. Yaemarunchai and C. Wutthivorawong. 2006. Seagrasses in Thai Waters. Phuket Marine Biological Center, Phuket (in Thai).

Rajamani, L. and H. Marsh. 2015. Mapping seagrass cost-effectively in the Coral Triangle: Sabah, Malaysia as a case study. Pac. Conserv. Biol. 21: 113.

Rozaimi, M., M. Fairoz, T.M. Hakimi, N.H. Hamdan, R. Omar, M.M. Ali and S.A. Tahirin. 2017. Carbon stores from a tropical seagrass meadow in the midst of anthropogenic disturbance. Mar. Pollut. Bull. 119: 253-260.

Short, F., T. Carruthers, W. Dennison and M. Waycott. 2007. Global seagrass distribution and diversity: a bioregional model. J. Exp. Mar. Biol. Ecol. 350: 3-20.

Sodhi, N.S., L.P. Koh, B.W. Brook and P.K. Ng. 2004. Southeast Asian biodiversity: an impending disaster. Trends. Ecol. Evol. 19: 654-660.

Sodhi, N., M. Posa, T. Lee, D. Bickford, L. Koh and B. Brook. 2010. The state and conservation of Southeast Asian Biodiversity. Biodivers. Conserv. 19: 317-328.

Soe-Htun, U., M.K. Wai, T.N. Soe, P.P. Kyawand and M.M. Aye. 2009. Seagrasses of Myanmar with special reference to the phytogeographic distribution of the species of ASEAN nations. J. Myanmar Acad. Art. Sci. 7: 363-387.

Southerland, M. 2016. China's Island Building in the South China Sea. In. U.S.-China Economic and Security Review Commission.

Spalding, M.D., H.E. Fox, G.R. Allen, N. Davidson, Z.A. Ferdaña, M. Finlayson, B.S. Halpern, M.A. Jorge, A. Lombana, S.A. Lourie, K.D. Martin, E. MaManus, J. Molnar, C.A. Recchia and J. Robertson. 2007. Marine Ecoregions of the World: a bioregionalisation of coastal and shelf areas. BioScience. 57: 573-583.

Tangaradjou, T., K. Sivakumar, E.P. Nobi and E. Dilipan. 2010. Distribution of seagrasses along the Andaman and Nicobar islands: a post tsunami survey Recent Trends in Biodiversity of Andaman and Nicobar Islands, pp. 157-160.

Tangsubkul, P. 1984. The Southeast Asian Archipelagic States: Conept, Evolution, and Current Practice. East-West Environment and Policy Institute Research Report No. 15.

Taplin, K.A., E.A. Irlandi and R. Raves. 2005. Interference between the macroalga Caulerpa prolifera and the seagrass Halodule wrightii. Aquat. Bot. 83: 175-186.

Theil, M., A. Penna-Díaz, G. Luna-Jorquera, S. Salas, J. Sellanes and W. Stotz. 2014. Citizen scientists and marine research: volunteer participants, their contributions, and projection for the future. Oceanogr. Mar. Biol. 52: 257-314.

Tiongson, A.J.C. 2012. Morphological differentiation of two populations of the seagrass Halophila spinulosa (R. Brown) Ascherson 
in Ilacaon Island, Negros Occidental, Philippines. in partial fulfillment for the degree of Bachelor of Science in Biology. Biology Department Silliman University, Dumaguete City 6200 Philippines. pp. 71.

Tittensor, D.P., C. Mora, W. Jetz, H.K. Lotze, D. Ricard, E. Vanden Berghe and B. Worm. 2010. Global patterns and predictors of marine biodiversity across taxa. Nature. 466: 1098-1101.

Torres-Pulliza, D., J.R. Wilson, A. Darmawan, S.J. Campbell and S. Andréfouët. 2013. Ecoregional scale seagrass mapping: a tool to support resilient MPA network design in the Coral Triangle. Ocean. Coast. Manage. 80: 55-64.

Tuntiprapas, P., S. Shimada, S. Pongparadon and A. Prathep. 2015. Is Halophila major (Zoll.) Miquel a big H. ovalis (R. Brown) J.D. Hooker? An evaluation based on age, morphology, and ITS sequence. ScienceAsia. 41: 79-86.

United Nations Environmental Programme (UNEP). 1995. Taking action, an environmental guide for you and your community. (A. Rogers, ed.), United Nations Environmental Programme, Nairobi, Kenya. pp. 23-60.

United Nations Environment Programme (UNEP). 2008. National Reports on Seagrass in the South China Sea. UNEP/GEF/SCS Technical Publication No. 12, pp. 207.

United Nations Environment Programme (UNEP). 2012. 21 Issues for the 21st century: result of the UNEP foresight process on emerging environmental issues. (J. Alcamo and S.A. Leonard eds). United Nations Environment Programme (UNEP), Nairobi, Kenya, pp. 56.

United Nations Environment Programme/South China Sea/Strategic Action Programme (UNEP SCS/SAP). 1999. Strategic Action Programme for the South China Sea Ver. $3(24 / 2 / 99)$.

Unsworth, R.K.F. 2010. Seagrass meadows of the Wakitobi National Park. In: (J. Clifton, R. Unsworth and D. Smith, eds) Marine research and conservation in the coral triangle. Nova Science Publishers Inc., UK. pp. 101-126.

Unsworth, R.K.F. and L.C. Cullen. 2010. Recognising the necessity for Indo-Pacific seagrass conservation. Conserv. Lett. 3: 63-73.

van der Zon, S. 2010. River influence on tropical seagrass ecosystems in the Derawan archipelago, East-Kalimantan, Indonesia. Master thesis Biology for Wageningen University and Radboud University Nijmegen.

van Katwijk, M.M., M.E.W. van der Welle, E. Lucassen, J.A. Vonk, M.J.A. Christianen, W. Kiswara, al Hakim I. II, A. Arifin, T.J. Bouma, J.G.M. Roelofs and L.P.M. Lamers. 2011. Early warning indicators for river nutrient and sediment loads in tropical seagrass beds: a benchmark from a near-pristine archipelago in Indonesia. Mar. Pollut. Bull. 62: 1512-1520.

van Katwijk, M.M., A. Thorhaug, N. Marbà, R.J. Orth, C.M. Duarte, G.A. Kendrick, I.H.J. Althuizen, E. Balestri, G. Bernard, M.L. Cambridge, A. Cunha, C. Durance, W. Giesen, Q. Han, S. Hosokawa, W. Kiswara, T. Komatsu, C. Lardicci, K. Lee, A. Meinesz, M. Nakaoka, K.R. O’Brien, E. Paling, C. Pickerell, A.M.A. Ransijn and J.J. Verduin. 2015. Global analysis of seagrass restoration: the importance of large-scale planting. J. Appl. Ecol. 53: 567-578.

Vermaat, J.E., R.N. Rollon, C.D.A. Lacap, C. Billot, F. Alberto, H.M.E. Nacorda, F. Wiegman and J. Terrados. 2004. Meadow fragmentation and reproductive output of the SE Asian seagrass Enhalus acoroides. J. Sea. Res. 52: 321-328.

Vibol, O., S. Nam, L. Puy and P.S. Wath. 2010. Seagrass diversity and distribution in coastal area of Kompot Province, Cambodia. Int. J. Environ. Rural. Dev. 1-2: 112-117.
Wagey, B. and H. Calumpong. 2013. Genetic analysis of the seagrass Halodule in Central Visayas, Philippines. Asian. J. Biodiv. 4. doi: 10.7828 /ajob.v4i1.318.

Wawan, K. 2011. Seagrasses in Indonesia. In: (H. Ogawa, B. Japar Sidik and Z. Muta Harah, eds.) Seagrasses: resource status and trends in Indonesia, Japan, Malaysia, Thailand and Vietnam. Seizando-Shoten Publishing Co., Ltd., Tokyo. pp. 5-16.

Waycott, M., D.W. Freshwater, R.A. York, A. Calladine and J.W. Kenworthy. 2002. Evolutionary trends in the seagrass genus Halophila (Thouars): insights from molecular phylogeny. Bull. Mar. Sci. 71: 1299-1308.

Waycott, M., K. McMahon, J. Mellors, A. Calladine and D. Kleine. 2004. A guide to tropical seagrasses of the Indo-West Pacific. Townsville, Australia: James Cook University.

Waycott, M., C.M. Duarte, T.J.B. Carruthers, R.J. Orth, W.C. Dennison, S. Olyarnik, A. Calladine, J.W. Fourqurean, K.L. Heck Jr., A. Randall Hughes, G.A. Kendrick, W. Judson Kenworthy, F.T. Short and S.L. Williams. 2009. Accelerating loss of seagrasses cross the globe threatens coastal ecosystems. Proc. Natl. Acad. Sci. USA 106: 12377-12381.

William, S.L. and K.L. Heck Jr. 2001. Seagrass community ecology. In: (M.D. Bertness, S.D. Gaines and M.E. Hay, eds.) Marine community ecology. Sinauer Associates, Sunderland, MA.

Yaakub, S.M., R.L.F. Lim, W.L. Lim and P.A. Todd. 2013. The diversity and distribution of seagrass in Singapore. Nat. Singapore 6: 105-111.

Yaakub, S.M., E. Chen, T.J. Bouma, P.L.A. Erftemeijer and P.A. Todd. 2014a. Chronic light reduction reduces overall resilience to additional shading stress in the seagrass Halophila ovalis. Mar. Pollut. Bull. 83: 467-474.

Yaakub, S.M., S. Lai, N.A. Rashid, R.L.F. Lim, W.L. Lim and L.J. McKenzie. 2014b. Monitoring Singapore's seagrass meadows: trends and highlights of the first long-term seagrass monitoring initiative. Poster presented at the Biodiversity Research Symposium, Singapore.

Yaakub, S.M., L.J. McKenzie, P.L.A. Erftemeijer, T. Bouma and P.A. Todd. 2014c. Courage under fire: seagrass persistence adjacent to a highly urbanised city-state. Mar. Pollut. Bull. 83: 417-424.

Young, P.C.and H. Kirkman. 1975. The seagrass communities of Moreton Bay, Queensland. Aquat. Bot. 1: 191-202.

\section{Bionotes}

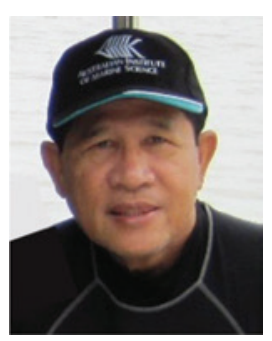

Miguel D. Fortes

Marine Science Institute, CS, University of the Philippines, Diliman, QC 1101, Philippines

Miguel D. Fortes is a coastal ecologist, biodiversity, ICZM and blue carbon specialist, focusing on seagrasses and mangroves. His works are major contributions to seagrass science and policy in the tropics. These have been making major impacts in relation to their applications and in the development of coastal resilience in the face of climate change and other environmental uncertainties. 


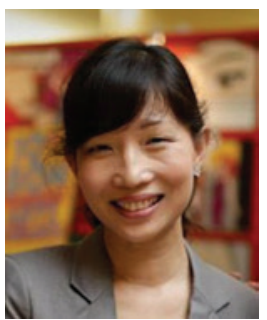

Jillian Lean Sim Ooi

Department of Geography, Faculty of Arts and Social Sciences, University of Malaya, Kuala Lumpur 50603, Malaysia

Jillian Lean Sim Ooi is a teaching and research academic at the Department of Geography, University of Malaya. Her early training was in environmental social science but she found talking to human subjects too difficult, and so shifted to studying plants. She has a $\mathrm{PhD}$ in seagrass biogeography from the University of Western Australia for her work on the spatial patterns and processes of seagrass in Johor, Malaysia. Her current focus is on understanding how these same meadows function as habitats for fish and as feeding grounds for dugongs and invertebrates. Her life-long goal is to set up a community arts centre-cum-marine research station on Siti Maryam Yaakub's seagrass island.

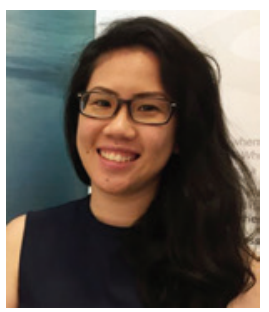

\section{Yi Mei Tan}

DHI Water and Environment (Singapore), 2 Venture Drive, \#18-18, Singapore 608526, Singapore

Yi Mei Tan is a marine ecologist trained at the University of Melbourne (BSc) and University of Aberdeen (MSc). She has broadbased interests in tropical marine ecosystems, but has since discovered a life consuming passion for seagrass. Yi Mei enjoys using GIS and spatial planning tools to aid in policy and marine conservation planning. Her life-long dream is to swim with orcas (but not be eaten alive), and to combine her newfound love of seagrass with her first love, fisheries research.

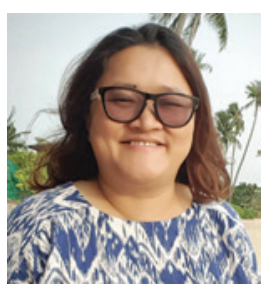

\section{Anchana Prathep}

Prince of Songkla University, Deparment of

Biology, Faculty of Science, Hat Yai, Thailand

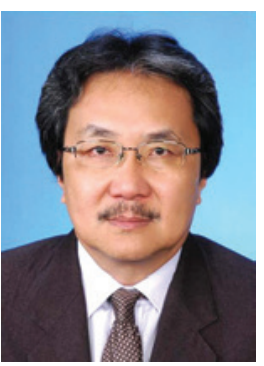

\section{Japar Sidik Bujang}

Department of Biology, Faculty of Science, Universiti Putra Malaysia, 43400 UPM Serdang, Selangor Darul Ehsan, Malaysia. http://orcid.org/0000-0002-9797-7963
Japar Sidik Bujang is Professor of Biology at Universiti Putra Malaysia (UPM). He was awarded a PhD in biology in 1989 by the Universiti Sains Malaysia, Penang, Malaysia for work on studies on leaf litter decomposition of the mangrove, Rhizophora apiculata Bl. He studied taxonomy, biology, and habitat characteristics of seagrasses and mangroves for over 26 years. His team has conducted studies on distribution, diversity and uses of aquatic macrophytes. Currently the team's research focus on identification of seagrass using morphology and molecular approaches, seagrass monitoring and adaptability to stressors, as well as techniques for the remote sensing of seagrass changes in coastal estuaries.

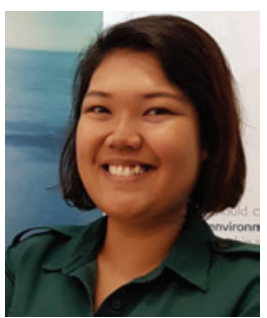

\section{Siti Maryam Yaakub}

Environment and Ecology Department, DHI Water and Environment (Singapore), 2 Venture Drive, \#18-18, Singapore 608526, Singapore, smj@dhigroup.cm. http://orcid.org/00000002-5703-5189

Siti Maryam Yaakub is a marine ecologist with experience working in the academic, government, and private sectors. A marine biologist by training with a broad understanding of marine ecosystems from mangroves to coral reefs, Siti specialised in seagrass ecosystems from an early stage. She has studied various aspects of seagrass biology and ecology including taxonomy, molecular genetics, ecology, restoration ecology, and physiology. Her life-long goal is to buy an island with seagrass and never retire from seagrass research.
Anchana Prathep leads the Seaweed and Seagrass Research Unit at Prince of Songkla University, Thailand. Her work focuses on seaweed and seagrass ecology, and she is recently trying to understand how much seaweeds and seagrasses contribute to carbon sequestration and storage, as well as how they respond to a changing world. 